\title{
Allometric approach to crop nutrition and implications for crop diagnosis and phenotyping. A review
}

\author{
Gilles Lemaire $^{1}$ (D) $\cdot$ Thomas Sinclair $^{2} \cdot$ Victor Sadras $^{3} \cdot$ Gilles Bélanger $^{4}$ \\ Accepted: 7 March 2019 / Published online: 8 April 2019 \\ (C) INRA and Springer-Verlag France SAS, part of Springer Nature 2019
}

\begin{abstract}
Historically, the agronomic focus of crop mineral nutrition has yielded responses to individual elements $(\mathrm{N}, \mathrm{P}, \mathrm{K} \ldots)$ to determine the economically optimum fertilization rates. This "prognostic" approach required several parameters for crops, climates, and soils that are often estimated with large uncertainty leading to over-fertilization and environmental problems in some systems (e.g., maize in China), and under-fertilization and soil mining in other systems (e.g., wheat in Australia).

In this review, an alternative approach is developed for reducing the uncertainty intrinsically linked to this prognostic approach. Our approach is based on four propositions: (1) the evidence of an allometry between the metabolic shoot mass (scaling with leaf area) and the structural shoot mass (supporting and vascular tissues) within plants that allows the formulation of critical $\mathrm{N}$ dilution curves and the determination of the Nitrogen Nutrition Index (NNI) for estimating the N nutrition status of field crops; (2) the coregulation of crop $\mathrm{N}$ uptake dynamics by both soil $\mathrm{N}$ supply and crop $\mathrm{N}$ demand in relation with its growth capacity that allows a better, more generalizable estimation of timing and rate of fertilizer; (3) a better understanding of the effects of genotypeenvironment-management interactions on $\mathrm{N}$ use efficiency in cropping systems reducing then drastically uncertainties linked to the classical prognostic approach for $\mathrm{N}$ fertilization; (4) as $\mathrm{P}$ and $\mathrm{K}$ also relate allometrically with biomass, $\mathrm{P}$ and $\mathrm{K}$ concentrations can be directly related to $\mathrm{N}$ concentration for the formulation of a multi-element diagnosis of crop nutrition. Here, we develop the theoretical background supporting these four propositions and outline implications for both fertilization management and crop phenotyping.
\end{abstract}

Keywords Crop N-P-K-S nutrition $\cdot$ Crop fertilization $\cdot$ Allometry in plants $\cdot$ Leaf area index $\cdot$ Crop diagnosis $\cdot \mathrm{N}$ dilution

Gilles Lemaire

gilles.lemaire.inra@gmail.com

Thomas Sinclair

trsincla@ncsu.edu

Victor Sadras

Victor.Sadras@sa.gov.au

Gilles Bélanger

Gilles.belanger@canada.ca

Honorary Director of Research, INRA, 86600 Lusignan, France

2 North Carolina State University, Raleigh, NC, USA

3 South Australian Research and Development Institute, Waite Campus, Urrbrae, Australia

4 Agriculture and Agri-Food Canada, Québec, Canada

\section{Contents}

1- Introduction

2- Classical analysis of crop nutrition

3- Dynamics of crop mass and nutrients accumulation

3.1 Resource capture and use by crops

3.2 Allometric approach

3.2.1 Dry matter allocation within plants and crops

3.2.2 $\mathrm{N}$ uptake and distribution in plants and canopies

3.2.3Extension to $\mathrm{P}$ and $\mathrm{K}$

4- Implications for management, phenotyping and further directions

4.1 Limits of the allometric approach of crop nutrition

4.2. Application for fertilization management

4.3. Perspectives for crop phenotyping

5- Conclusions 


\section{Introduction}

Historically, crop yield has been closely linked with nutrient availability to plants, particularly nitrogen $(\mathrm{N})$ (Sinclair and Sinclair 2010). Until the $18^{\text {th }}$ century, cereal grain yields in Europe were no more than $1 \mathrm{t} \mathrm{ha}^{-1}$ reflecting the low $\mathrm{N}$ input of less than $15-20 \mathrm{~kg} \mathrm{ha}^{-1}$ to cropping systems from natural processes such as lightning and $\mathrm{N}_{2}$ fixation by free-living soil microbes. The advent of the "Norfolk rotation" in England in the $18^{\text {th }}$ century resulted in the doubling of grain yields to about $2 \mathrm{tha}^{-1}$. This rotation included 2 to 3 years of a clover/ryegrass mixture that provided the additional $\mathrm{N}$ to support the wheat yield increase. From the end of the Second World War until the end of the 20th century, the huge increase in global cereal production has been associated with a 7-fold increase in the use of $\mathrm{N}$ fertilizers and a 3.5-fold increase in the use of phosphorus (P) fertilizers (Tilman et al. 2002). As industrial production of $\mathrm{N}$ fertilizer depends on fossil energy and is associated with high greenhouse gas emissions, and $\mathrm{P}$ fertilizer is non-renewable, these two nutrients have to be used more efficiently in cropping systems.

The future in improved nutrient management is not altogether clear. Worldwide, cropping systems are diverse and can be segregated into at least two different levels of intensification (Fischer and Connor 2018). In low input systems, because of water scarcity and/or low access of farmers to technology and financial resources, under-fertilization can lead to soil mining and soil degradation (Angus and Grace 2017). In high input systems, more precise management of fertilizers is necessary to maintain or even continue to increase crop yield, while resorbing the excess of $\mathrm{N}$ and $\mathrm{P}$ flows across agroecosystems and the associated environmental impacts (Galloway and Cowling 2002). To account for the diversity of biotic and abiotic variables that affects nutrient use, quantitative tools are required to assess nutrient influence on crop growth and yield. In recent years, such quantitative tools have been developed for $\mathrm{N}$ and they offer guideposts for expanding the understanding to other nutrients such as $\mathrm{P}$, potassium $(\mathrm{K})$, and sulfur (S).

The objectives of this paper are

1. To briefly review the classical analysis of crop nutrition and its limitations

2. To consider process-based perspectives linking growth and $\mathrm{N}$, and their limitations

3. To examine allometric approaches for describing crop growth responses to $\mathrm{N}$

4. To consider extension of the allometric approach from $\mathrm{N}$ to $\mathrm{P}$ and $\mathrm{K}$, and accounting for interactions and colimitations among nutrients

5. To outline the implications of this integrated approach for the diagnosis of crop nutrition, the interpretation of genotype-environment-management interactions in terms of nutrient-use efficiency, and crop phenotyping

\section{Classical analysis of crop nutrition}

The scientific analysis of crop nutrition mostly evolved from the work of Jean Baptiste Boussingault (1855) who proved the link between $\mathrm{N}$ accumulation in plants and soil nitrate fertility. At about the same time, Justus von Liebig (1855) developed the Law of the Minimum: "plants grow only to the extent allowed by the single nutrient that is most limiting". It is now clear that the Law of the Minimum fails to capture interactions among nutrients, and between nutrients and other resources including water (Sinclair and Park 1993; Cossani and Sadras 2018).

Recognizing the limitation of von Liebig's theory, Liebscher (1895) proposed the Law of the Optimum: "all nutrients are used most efficiently when the availability of the nutrient that is most limiting is increased near its optimum". While the Law of the Optimum is more consistent with observations (de Wit 1992), the approach remains static and offers no universal insight about crop nutrient uptake and allocation, nor does it account for the temporal dynamics of crop growth and nutrient accumulation, and partitioning throughout a growing season.

The initial analysis of crop nutrition led to empirical curves relating crop yield with nutrient availability for the purpose of fertilizer recommendations. Although those empirical curves and their related recommendations have helped to improve crop nutrition, they do not capture the seasonal dynamics of nutrients in soils and crops, nor the intra- and inter-seasonal variation in weather, particularly rainfall. Response curves apply to the conditions under which the data were collected, but they cannot be extrapolated, leading to large uncertainties and limited conclusions.

Response curves to $\mathrm{N}$ fertilization averaged across sites and seasons are still the basis for $\mathrm{N}$ fertilizer recommendations in many cropping systems (Fig. 1), but they can lead to overfertilization and high residual soil nitrates in some systems, for example for potato in Canada (Bélanger et al. 2003). Those "average" response curves do not take into account the large site-to-site and seasonal variation in the yield response to $\mathrm{N}$ (Bélanger et al. 2000). In systems where $\mathrm{N}$ fertilizer is costly or less accessible for other reasons, crops are typically underfertilized (Monjardino et al. 2013, 2015; Dimes et al. 2015) at the risk of soil mining (Angus and Grace 2017).

Most tools for crop nutrition diagnosis and fertilizer decisions are based on soil or plant tests. For instance, the soil N supply can be estimated through the calculation of balances between net $\mathrm{N}$ mineralization, $\mathrm{N}$ leaching and volatilization, and soil N mineral content (Machet et al. 2017). However, this "prognosis" approach suffers from a large uncertainty in estimates of crop $\mathrm{N}$ demand because of growth and yield variations with soil attributes, weather, and crop management. Moreover, Ravier et al. (2016) showed that the application of this method by farmers generally leads to over- 


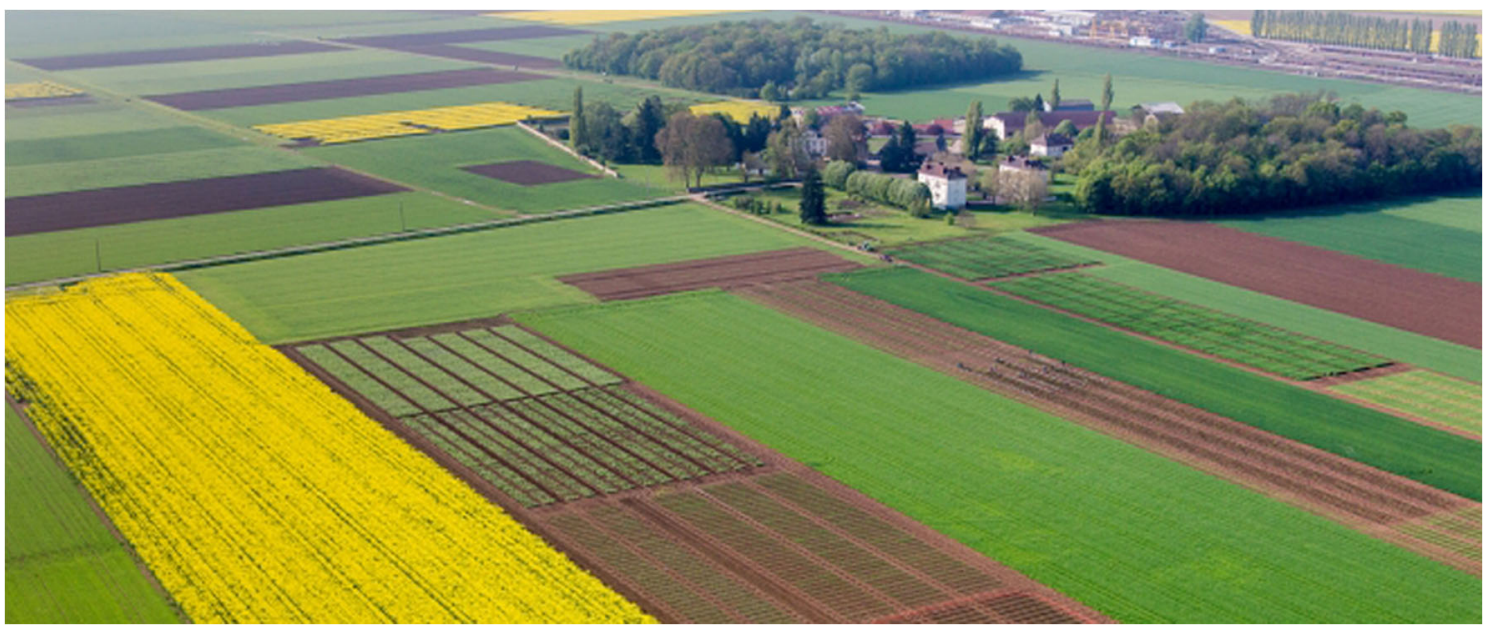

Fig. 1 Crop fertilization management is based on empirical crop responses to timing and rate of fertilizer application (photo INRA; Experimental fields, Domaine Epoisses, Dijon, France)

fertilization because of a tendency for over-estimating the target yield. Soil nitrate tests, either prior to sowing or in midseason, to determine the required $\mathrm{N}$ fertilizer have been used with mixed results. This approach usually works well in drier areas but has been shown to be less effective in humid areas of Canada for potatoes and spring wheat, particularly when used pre-sowing (Bélanger et al. 1998, 2001b). In environments where crops rely on uncertain seasonal rainfall, uncertain target yield is the bottleneck to determine $\mathrm{N}$ fertilizer requirements (Monjardino et al. 2013).

For $\mathrm{P}$ and $\mathrm{K}$, recommendations are usually based on soil tests for evaluating the available $\mathrm{P}$ and $\mathrm{K}$ mineral stocks for comparison with yield responses to further nutrient applications. The degree of success of soil chemical extractions to estimate the amount of $\mathrm{P}$ available to crops and their interpretation in predicting the amount of $\mathrm{P}$ fertilizer needed to reach near maximum crop yield is, however, limited (Valkama et al. 2011; Bélanger et al. 2015a, b, 2017). In some cropping systems, a simple threshold defining non-limiting and limiting nutrient conditions has been practiced. This approach can result in over-fertilization but has been accepted where the cost of fertilizer is a small component of production costs (e.g., in subsidized systems), or in industries such as horticulture with intrinsically highvalue crops (Jobbágy and Sala 2014).

Plant tissue analyses for crop nutrition diagnosis are based on the nutrient concentration of specific organs (e.g., leaves, petioles, stem bases) or of whole plants. These methods rely on the definition of a critical concentration, that is, concentrations required to achieve maximum shoot growth and yield. In most cases, however, critical concentrations are based on empirical relationships that cannot be generalized or extrapolated to diverse situations (Smith 1962; Walworth and Summer 1987).

\section{Dynamics of crop mass and nutrient accumulation}

For most crop species, the life cycle can be divided into two main periods: (i) the vegetative phase, when developing leaves, roots, and stems are sinks for both photo-assimilates and reduced $\mathrm{N}$ compounds and (ii) the reproductive phase during which senescing vegetative tissues are sources of carbon (C) and mobile nutrients for developing reproductive and/ or storage organs (Lemaire 2015). This distinction is convenient for our analysis, but the vegetative and reproductive phases often overlap to different degrees depending on the species (Cohen 1971; Amir and Cohen 1990).

The vegetative phase is essential for the accumulation of biomass and nutrients that contributes to yield formation. For grain crops, grain yield is first determined by the crop mass and nutrient accumulated at the end of this vegetative phase, and by grain filling associated with further nutrient uptake and translocation during the reproductive phase. However, most of the nutrient uptake occurs in the vegetative phase and, consequently, the primary focus of this paper is the vegetative phase when most decisions on fertilization are taken. Some aspects related to the reproductive phase, particularly important for grain crops, are also considered.

\subsection{Resource capture and use by crops}

Contemporary crop growth analysis is based on the concept of the capture of resources and the efficiency with which they are used. Crop canopies capture $\mathrm{CO}_{2}$ and radiation from the atmosphere, while roots capture water and nutrients from the soil (Monteith 1994). The capture of water and its interaction with $\mathrm{N}$ are important, but they are out of the scope of this review. Recent analyses of this interaction can be found in Kunrath et al. (2018) for perennial forage crops and in 
Cossani and Sadras (2018) for grain crops. Here, we focus on three processes:

1. Capture of radiation and $\mathrm{CO}_{2}$ by crop canopies

2. Uptake of nutrients by plants and crops

3. Allocation of mass and nutrients to plant organs through morphogenesis that drives the size, architecture, and functionality of the crop canopy and the root system

The processes of capture and allocation of $\mathrm{C}$ and nutrients are highly coupled with positive feedbacks and tradeoffs. A greater allocation of resources to the crop canopy favors $\mathrm{C}$ assimilation, whereas a greater allocation to roots favors nutrient and water uptake (Lambers 1983). Crop growth is proportional to the amount of photosynthetic active radiation (PAR) intercepted by the crop canopy and radiation use efficiency (RUE) (Monteith 1972):

$\mathrm{W}_{\mathrm{t}}=\mathrm{RUE} \times \sum(\mathrm{PARi})$

where $\mathrm{W}_{\mathrm{t}}$ is the total crop dry matter mass (shoot + root) in $\mathrm{g}$ dry matter $(\mathrm{DM}) \mathrm{m}^{-2}, \sum$ (PARi) is the cumulative amount of photosynthetically active radiation intercepted by the crop canopy in $\mathrm{MJ} \mathrm{m}^{-2}$, and RUE represents the integrated net dry mass accumulation and is expressed in $\mathrm{g} \mathrm{DM} \mathrm{MJ}^{-1}$. This model, often simplified by excluding roots, has been shown to be appropriate for perennial forage crops such as alfalfa (Gosse et al. 1984) and tall fescue (Bélanger et al. 1992a) and for annual crops such as wheat (Sinclair and Amir 1992; Sinclair et al. 1993), maize (Muchow and Sinclair 1993) and sorghum (Sinclair et al. 1997).

Nitrogen deficiency affects crop growth by reducing the capture of radiation, the radiation use efficiency, or both. Nitrogen deficiency reduces the leaf expansion rate as a consequence of reduced rates of cell division and expansion in meristems (Gastal et al. 1992; Gastal and Nelson 1994; Trapani et al. 1999). Severe N deficiencies can also increase the rate of leaf senescence, further contributing to a smaller crop canopy and reduced capture of radiation (Thomas and Ougham 2015). Nitrogen deficiency can also decrease the leaf photosynthetic capacity and RUE (Sinclair and Horie 1989; Connor et al. 1993; Grindlay 1997). However, N deficiency favors the mobilization of $\mathrm{N}$ from shaded leaves at the bottom of the canopy to upper leaves, buffering the effect on RUE (Sinclair and Horie 1989; Gastal and Bélanger 1993; Bélanger et al. 1994; Gastal and Lemaire 2002). Consequently, the main effect of $\mathrm{N}$ deficiency is a reduction in growth primarily through a reduction in canopy leaf area and the capture of radiation (Bélanger et al. 1994).

Phosphorus deficiency also reduces the leaf expansion rate through its effects on the rate of cell production (Assuero et al. 2004) and decreases crop growth by reducing PAR interception rather than by decreasing RUE (Plénet et al. 2000).
Potassium deficiency decreases the leaf area index (LAI) of maize through both reduction of leaf appearance rate and leaf size (Jordan-Meille and Pellerin 2004). Even a mild K deficiency affected cotton leaf expansion but only a severe $\mathrm{K}$ deficiency decreased leaf photosynthesis (Gerardeaux et al. 2010). All these results indicate a generalized response of crops to abiotic stresses, including nutrient deficiency, of a reduction in crop growth by primarily affecting the LAI and the capture of radiation (Connor and Sadras 1992; Sadras et al. 2005; Valle et al. 2009).

This overview of the processes defining crop growth highlights the importance of canopy leaf area and, hence, the need to model LAI expansion accounting for genotype, temperature, and the supply of water, N, and P. The difficulty for modeling this important trait is the scaling gap between leaf area expansion, a two-dimensional process, and crop mass accumulation, a three-dimensional process, if we assume an approximately constant dry matter content per unit of plant volume. Most crop models circumvent this difficulty by using empirical algorithms for dry matter allocation to plant morphological compartments (root, leaves, and stems) for estimating LAI expansion dynamics directly from shoot dry matter accumulation:

$\mathrm{LAI}=\mathrm{W}_{\mathrm{t}} \times\left(\mathrm{dW}_{\mathrm{sh}} / \mathrm{dW}_{\mathrm{t}}\right) \times\left(\mathrm{dW}_{\mathrm{l}} / \mathrm{dW}_{\mathrm{sh}}\right) \times \mathrm{SLA}$

with $\mathrm{W}_{\mathrm{t}}$ the total dry matter as resulting from Eq. (1), $\mathrm{dW}_{\mathrm{sh}} /$ $\mathrm{dW}_{\mathrm{t}}$ the fractional allocation of dry matter to shoots, $\mathrm{dW}_{\mathrm{l}} /$ $\mathrm{dW}_{\mathrm{sh}}$ the fractional allocation of shoot dry matter to leaves (e.g., leaf/stem ratio), and SLA the specific leaf area (leaf mass per unit leaf area). In many models, these fractional allocation coefficients are empirically fixed involving critical threshold values associated with plant ontogeny. Equations $(2)+(1)$, therefore, define the increase in LAI based on the next increment in $\sum$ PARi and in $\mathrm{W}_{\mathrm{t}}$, usually done on daily iterations. But such algorithms, even if they allow empirical simulations of LAI, do not represent any physiological processes and can lead to circularity.

Mechanistic models seek to simulate the processes that directly influence leaf area development. For example, the SSM model described in detail by Soltani and Sinclair (2012, 2015) and Soltani et al. (2013) postulates that LAI expansion is driven by temperature that determines leaf $\mathrm{N}$ demand based on a critical $\mathrm{N}$ content per unit leaf area. Also, the stem fraction of shoot mass is determined by the $\mathrm{C}$ supply with a variable $\mathrm{N}$ concentration. Such models partially capture the primordial role of $\mathrm{N}$ supply in dry matter allocation within canopies, and the secondary dependency of leaf expansion from photosynthesis. This contrasts to Eq. (2) where LAI results from empirical allocation coefficients. Nevertheless, even if these models represent a progress in understanding, some threshold values for minimum $\mathrm{N}$ concentration in plant tissues are usually required. 
Furthermore, the study of $\mathrm{C}$ and $\mathrm{N}$ partitioning between roots and shoots has to move from a morphological to a more functional viewpoint as discussed by Lemaire and Millard (1999). Körner (1991) showed that, in terms of resource capture, only the allocation between leaves and fine roots is relevant, while the shoot/root mass ratio across a large range of species often results from the partitioning between stems and coarse (or tap) roots having storage or anchorage functions. Using the model of Minchin et al. (1993) for C and N substrate transport and allocation within plants, Lemaire and Millard (1999) showed that the allocation of dry matter to shoot meristems for leaf area expansion always has the priority leading to an increase in the proportion of assimilates allocated to shoots at the expense of roots (Farrar 1988; Durand et al. 1989; Bélanger et al. 1994). This approach accounts for the higher shoot/root ratio of plants grown under high temperatures or N supply (Durand et al. 1991).

The allocation of assimilates to leaf meristems for leaf area expansion is a dynamic process that modulates the capture of PAR and, hence, drives growth (Eq. 1). This priority for assimilate use in shoots allows a positive feedback for crop growth until the maximum LAI is achieved. This priority for leaves is emphasized by the $\mathrm{N}$ and $\mathrm{P}$ supply at the expense of root expansion. However, if $\mathrm{N}$ and $\mathrm{P}$ deficiencies restrict shoot demand, then a greater allocation to roots becomes possible that partially restores the nutrient capture capacity of the plant as proposed by the functional equilibrium concept (Brouwer 1963).

\subsection{Allometric approach}

\subsubsection{Dry matter allocation within plants}

Allocation of $\mathrm{C}$ and nutrients in plants is central to crop growth and differences in allocation patterns among species reflect response strategies to differing selection pressures (Stearns 1992). These strategies are indicative of varying physiological mechanisms and ecological performance (Körner 1991; Niklas 1994; Schwinning and Weiner 1998). Allocation patterns are under genetic control (Körner 1991; Weiner 2004), as illustrated by dwarfing genes that decrease dry matter allocation to stems and increase allocation to grains in cereals (Fischer and Stockman 1986; Youssefian et al. 1992). However, allocation patterns are plastic in response to the abiotic or biotic environment (Bradshaw 1965; Andrews et al. 1999). A noticeable consequence of this plasticity is the phenotypic range that can be expressed by plants of a similar genotype.

Growth of plant parts commonly tracks well-defined allometric trajectories (Weiner 2004). An example of such an allometric trajectory is the relationship between dry matter allocated to shoots $\left(\mathrm{W}_{\mathrm{sh}}\right)$ and total plant mass $\left(\mathrm{W}_{\mathrm{t}}\right)$ (Weiner 2004)

$\mathrm{W}_{\mathrm{sh}}=\mathrm{k} \times\left(\mathrm{W}_{\mathrm{t}}\right)^{\curlyvee}$

with $\Upsilon$ as a scaling coefficient equal to the ratio between relative shoot growth rate $\left[1 / \mathrm{W}_{\text {sh }} \times \mathrm{d}\left(\mathrm{W}_{\text {sh }}\right) / \mathrm{dt}\right]$ and relative plant growth rate $\left[1 / \mathrm{W}_{\mathrm{t}} \times \mathrm{d}\left(\mathrm{W}_{\mathrm{t}}\right) / \mathrm{dt}\right]$. Modifying Eq. (3) by dividing both sides by $\mathrm{W}_{\mathrm{t}}$, an expression of the ratio $\mathrm{W}_{\mathrm{sh}} / \mathrm{W}_{\mathrm{t}}$ is obtained:

$\mathrm{W}_{\mathrm{sh}} / \mathrm{W}_{\mathrm{t}}=\mathrm{k} \times\left(\mathrm{W}_{\mathrm{t}}\right)^{\Upsilon-1}$

Equation (4) shows explicitly that the $\mathrm{W}_{\mathrm{sh}} / \mathrm{W}_{\mathrm{t}}$ ratio is not constant within a growing season since it depends on $\mathrm{W}_{\mathrm{t}}$. Using ${ }^{14} \mathrm{C}$ labeling in grass swards with different $\mathrm{N}$ treatments, Bélanger et al. (1992b) showed that shoots used a decreasing proportion of newly assimilated $\mathrm{C}$ when the existing amount of $\mathrm{C}$ in shoots increased. This decrease can be described by an allometry with a scaling coefficient of 0.62 under non-limiting $\mathrm{N}$, while this coefficient drops to 0.78 under limiting $\mathrm{N}$ supply. Hence, the $\mathrm{W}_{\mathrm{sh}} / \mathrm{W}_{\mathrm{t}}$ ratio has an "apparent plasticity" depending on the shoot mass as it varies with age or environmental factors such as the atmospheric $\mathrm{CO}_{2}$ concentration, and the supply of $\mathrm{N}$ or water (Evans 1972; McConnaughay and Coleman 1999). As a result, the allometric expression of growth can be seen as a timedependent process, since both $\mathrm{W}_{\mathrm{t}}$ and $\mathrm{W}_{\mathrm{sh}}$ vary during the growing season. Similar allometric relationships describe the allocation of shoot mass between leaves and stems, whereby the leaf/stem ratio declines with plant ontogeny for forage species such as timothy (Bélanger et al. 2001a) or alfalfa (Lemaire et al. 1989), and for cereals (Hoogmoed and Sadras 2018).

Weiner (2004) suggested that an allometric relationship has to be considered as the null hypothesis for studying the allocation of dry matter in plants and crops in response to genotype, resources (water, nutrients, $\mathrm{CO}_{2}$, and radiation), and non-resource factors (e.g., temperature, light quality, mechanical constraints). The pattern of allocation could then be separated into two components. One component is the massdependent variation in allocation; this has been termed "ontogenetic drift" (Evans and Hughes 1961; Evans 1972). A second component is the mass-independent variation in allocation through modification of the allometry trajectory, reflected in scaling coefficients and variation in partitioning ratios (shoot/root or leaf/stem) at a similar shoot mass as illustrated in Fig. 2.

Analogous to Eq. (3), Lemaire et al. (2007) showed that the crop leaf area index (LAI) is allometrically related to $\mathrm{W}_{\mathrm{sh}}$ during vegetative growth:

$\mathrm{LAI}=\mathrm{k} \times\left(\mathrm{W}_{\mathrm{sh}}\right)^{\alpha}$ 


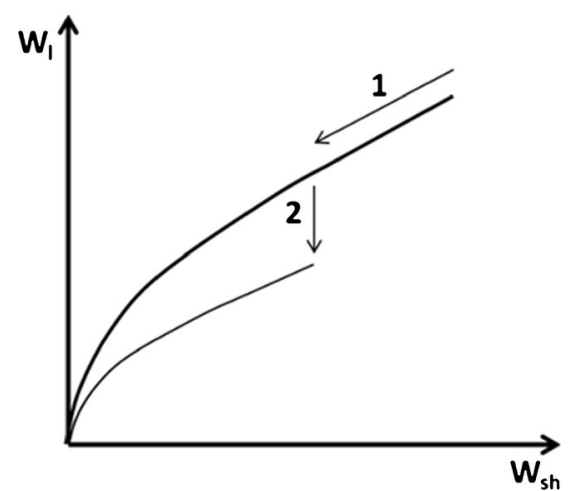

Fig. 2 Illustration of the mass-dependent (arrow 1) and the massindependent (arrow 2) variations of the fractional allocation of dry matter to leaves $\left(\mathrm{W}_{1}\right)$ with shoot biomass $\left(\mathrm{W}_{\mathrm{sh}}\right)$. In this example, the allometric coefficient is less than 1 , and consequently the $\mathrm{W}_{1} / \mathrm{W}_{\text {sh }}$ ratio declines as $\mathrm{W}_{\mathrm{sh}}$ increases

The scaling coefficient $\alpha$ depends on the LAI of the canopy. For LAI $>1, \alpha$ is close to 0.67 , while $\alpha$ is near 0.90 for a sparse canopy $(\mathrm{LAI}<1)$ or isolated plants. This is illustrated for wheat in Fig. 3 where the linear, natural logarithm form of Eq. (5) is used to solve for $\alpha$ as the slope. In this case, $\alpha$ was 0.93 when LAI was less than 1 and 0.60 when LAI was greater than 1. Comparisons across a wide range of species, including $\mathrm{C} 3$ vs. C4 and monocot vs. dicot, confirm the stability of $\alpha$ (Table 1) and the generality of distinction between "open" and "closed" crop canopies. In the absence of competition for light (isolated plants), high $\alpha$ indicates growth favoring leaf expansion. In canopies with large leaf area, the allocation to stems increases at the expense of the allocation to leaves.

Given that $\alpha$ is less than 1.0 in all cases, Eq. (5) indicates that, as shoot mass increases, a smaller proportion of dry matter is allocated to leave area expansion while a greater proportion of dry matter is allocated to structural tissues such as stems, petioles, or leaf midribs. This dynamics of allocation reflects an "increasing dry matter cost" for new leaf area expansion. As detailed in Box 1, this increase in dry matter cost for new leaf area expansion can be interpreted as a consequence of changes in plant allocation resulting from a shade-avoidance adaptation of individual plants mediated by photo-morphogenesis (Ballaré et al. 1995).

Box 1 Quality and amount of light modulates allocation of dry matter and $\mathrm{N}$ in crops

Isolated plants without interacting neighbors have a mass allocation to leaves that favors light capture. But in the presence of neighbors, patterns of allocation are modulated by the shifts in the light environment including changes in light quality (red-far red ratio and blue light) and decreased irradiance at the bottom of high-LAI canopies (Aphalo and Ballaré 1995; Ballaré et al. 1997). This light environment enhances the allocation of dry matter to vertical and thickness structures that favor N-poor plant components including stem internodes, leaf petioles, and midribs that accelerate the $\mathrm{N}$ dilution process.

Moreover, the profile of foliar $\mathrm{N}$ allocation within canopies is related to the light extinction profile (Hirose and Werger 1987; Lemaire et al.

1991; Anten et al. 1995; Sadras et al. 2012) and this contributes also to $\mathrm{N}$ dilution at the whole crop level.

The allometries between LAI or $\mathrm{N}_{\text {upt }}$ and $\mathrm{W}_{\text {sh }}$ are based on (a) the scaling between leaf area and the mass of active plant tissues responsible for growth, and (b) the proportionality between plant growth rate in high LAI canopies and $\mathrm{W}_{\mathrm{sh}}{ }^{2 / 3}$, as postulated by Hardwick (1987). This model is also convergent with the general self-thinning law in ecology of a power relationship of $-3 / 2$ between plant mass and plant density within high LAI plant stands (Yoda et al. 1963; Sackville-Hamilton et al. 1995). All these relationships are interpreted by the fact that the light environment within high-LAI canopies favors an isometric growth of plants, i.e., similar relative growth rates in the three dimensions that maintain leaf area within the well illuminated layers of the canopy. Consequently, each increment in leaf area is accompanied by an increasing quantity of structural tissues (Niklas 1994).

Equation (5) can be divided by $\mathrm{W}_{\mathrm{sh}}$ to obtain an expression for the leaf area ratio (LAR, leaf area divided by shoot mass) as a function of shoot mass:
Fig. 3 Allometry between crop LAI and crop dry mass for wheat from seedlings to $\mathrm{LAI}=1$ [triangles; $\mathrm{LAI}=\left(0.93 \mathrm{xW}_{\mathrm{sh}}\right)+$ $\left.0.34, R^{2}=0.90\right]$ and from $\mathrm{LAI}=1$ to heading [squares;

$\mathrm{LAI}=\left(0.60 \mathrm{xW}_{\mathrm{sh}}\right)+0.34, \mathrm{R}^{2}=$ 0.91]. After Lemaire et al. (2007)

\section{Ln LAI}

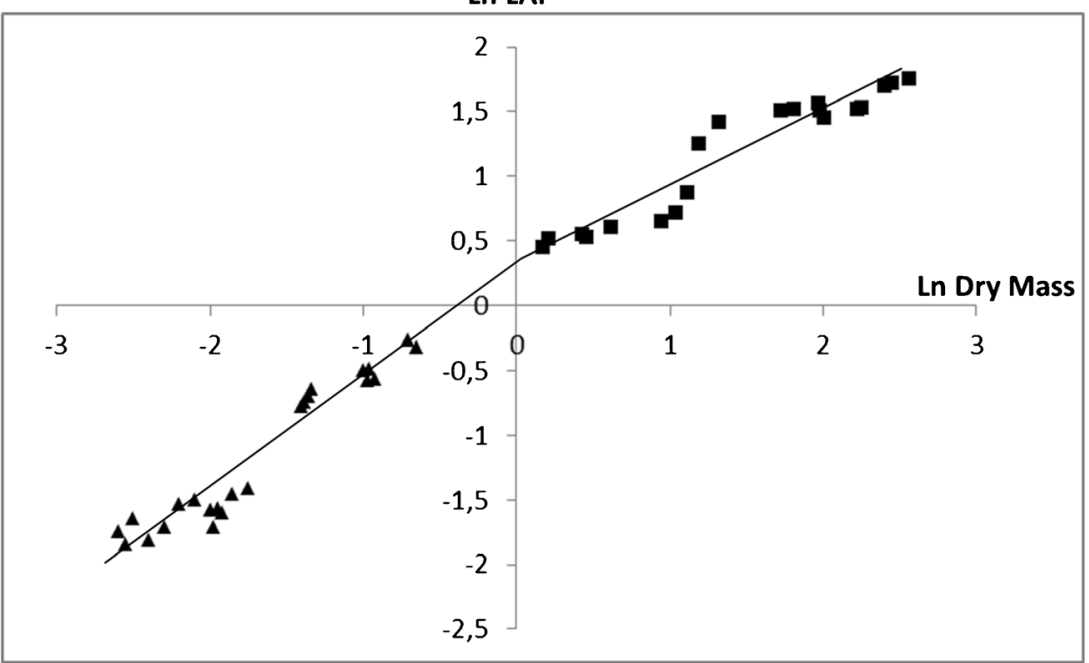


Table 1 Values of allometric coefficients " $b$ " in $\mathrm{N}_{\text {upt }}=\mathrm{a} \times\left(\mathrm{W}_{\text {sh }}\right)^{\mathrm{b}}$ and " $\alpha$ " in LAI $=\mathrm{k} \times\left(\mathrm{W}_{\mathrm{sh}}\right)^{\alpha}$ for isolated plants with subscript "i" ( $\mathrm{b}_{\mathrm{i}}$ and $\left.\alpha_{\mathrm{i}}\right)$ and a dense crop with subscript " $\mathrm{d}$ " $\left(\mathrm{b}_{\mathrm{d}}\right.$ and $\alpha_{\mathrm{d}}$ ) for a range of crop species, and values of coefficient " $\mathrm{k}$ " (plant leafiness) and coefficient $\mathrm{a} / \mathrm{k}$ of Eq. (17), the quantity of $\mathrm{N}$ uptake per unit LAI expressed as $\mathrm{kg}$ $\mathrm{N} \mathrm{ha}^{-1} \mathrm{LAI}^{-1}$. After Lemaire et al. (2007)

\begin{tabular}{|c|c|c|c|c|c|c|}
\hline \multirow[t]{2}{*}{ Species } & \multicolumn{2}{|c|}{ Isolated plant } & \multicolumn{2}{|c|}{ Dense crop } & \multirow[b]{2}{*}{$\mathrm{k}$} & \multirow[b]{2}{*}{$\mathrm{a} / \mathrm{k}$} \\
\hline & $b_{i}$ & $\alpha_{i}$ & $b_{d}$ & $\alpha_{d}$ & & \\
\hline Alfalfa & 0.90 & 0.89 & 0.67 & 0.67 & 1.94 & 25 \\
\hline Canola & 0.84 & 0.78 & 0.75 & 0.72 & 1.59 & 26 \\
\hline Sunflower & 0.97 & 0.95 & 0.55 & 0.50 & 1.83 & 27 \\
\hline Wheat & 0.92 & 0.89 & 0.56 & 0.61 & 1.13 & 39 \\
\hline Rice & 0.91 & 0.98 & 0.58 & 0.63 & 1.31 & 32 \\
\hline Sorghum & 0.94 & 0.95 & 0.61 & 0.65 & 1.41 & 24 \\
\hline Maize & 0.94 & 0.95 & 0.63 & 0.71 & 1.06 & 32 \\
\hline Mean & 0.91 & 0.89 & 0.62 & 0.63 & & \\
\hline
\end{tabular}

$\mathrm{LAR}=\mathrm{k} \times\left(\mathrm{W}_{\mathrm{sh}}\right)^{\alpha-1}$

Since $\alpha-1<0$, this equation predicts that the LAR declines as shoot mass increases.

\subsubsection{Nitrogen uptake and distribution in plants and canopies}

An allometric approach was developed to express $\mathrm{N}$ uptake and distribution in crops not unlike the approach described above for plant mass changes. Lemaire and Salette (1984a, b) and Greenwood et al. (1990) showed that shoot $\mathrm{N}$ uptake $\left(\mathrm{N}_{\text {upt }}, \mathrm{kg} \mathrm{ha}^{-1}\right.$ ) was related to $\mathrm{W}_{\mathrm{sh}}$ when $\mathrm{W}_{\text {sh }}$ was greater than $1 \mathrm{tha}^{-1:}$

$\mathrm{N}_{\text {upt }}=\mathrm{a} \times\left(\mathrm{W}_{\mathrm{sh}}\right)^{\mathrm{b}}$

The allometry between $\mathrm{N}_{\text {upt }}$ and $\mathrm{W}_{\text {sh }}$ offers insight about crop $\mathrm{N}$ use efficiency (Box 2).

Box 2: Consequences for assessing $\mathrm{N}$ use efficiency by crops

Derivative of Eq. (7) with time allows the expression of the rate of crop N uptake $\left(\mathrm{dN}_{\mathrm{upt}} / \mathrm{dt}\right)$ in relation with the crop growth rate $\left(\mathrm{dW}_{\mathrm{sh}} / \mathrm{dt}\right)$ and the shoot mass $\left(\mathrm{W}_{\mathrm{sh}}\right)$ :

$\mathrm{dN}_{\text {upt }} / \mathrm{dt}=\mathrm{abW}_{\text {sh }}{ }^{\mathrm{b}-1} \times \mathrm{dW}_{\mathrm{sh}} / \mathrm{dt} \operatorname{Eq}\left(7^{\prime}\right)$

Under non-limiting $\mathrm{N}$ supply, the crop $\mathrm{N}$ uptake rate $\left(\mathrm{dN}_{\text {upt }} / \mathrm{dt}\right)$ depends on the potential crop mass accumulation rate $\left(\mathrm{dW}_{\mathrm{sh}} / \mathrm{dt}\right)$, but it declines as crop mass increases. Devienne-Barret et al. (2000) showed that the rate of crop $\mathrm{N}$ uptake is dependent on both crop growth rate and soil $\mathrm{N}$ availability leading to a family of $\mathrm{N}_{\mathrm{upt}}-\mathrm{W}_{\mathrm{sh}}$ trajectories for each steady-state condition of soil $\mathrm{N}$ supply as represented in Fig. 4. This dual dependency of $\mathrm{N}$ uptake is well explained by physiological evidence on feedback regulation of root absorption capacity of mineral $\mathrm{N}$ (nitrate and ammonium) by shoot growth through $\mathrm{C}$ and $\mathrm{N}$ signals (Gastal and Saugier 1989; Lejay et al. 1999).
If $\mathrm{N}_{\mathrm{f}}$ represents the rate of $\mathrm{N}$ fertilizer application, the nitrogen use efficiency (NUE $=\mathrm{dW}_{\mathrm{sh}} / \mathrm{dN}_{\mathrm{f}}$ ) for crop mass production is a function of two components: (i) the $\mathrm{N}$ absorption efficiency (NAE $=\mathrm{dN}_{\text {upt }} / \mathrm{dN}_{\mathrm{f}}$ ) and (ii) the $\mathrm{N}$ conversion efficiency $\left(\mathrm{NCE}=\mathrm{dW}_{\mathrm{sh}} / \mathrm{dN}_{\text {upt }}\right)$, so that

$\mathrm{NUE}=\mathrm{NAE} \times \mathrm{NCE}$

$\mathrm{dN}_{\mathrm{f}}$ being the increment in $\mathrm{N}$ fertilization rate. Then, the $\mathrm{N}_{\text {upt }}$ $\mathrm{W}_{\text {sh }}$ allometry has two important consequences for analyzing variations in NUE due to genotype-environment-management interactions as underlined by Sadras and Lemaire (2014):

1. NAE is partly determined by crop growth rate so that genotypes having a higher crop mass should have a higher NAE than slow growing genotypes. This effect is shown on Fig. 4 where any increment in $\mathrm{W}_{\mathrm{sh}}$ is associated with a corresponding increment of $\mathrm{N}_{\text {upt }}$ for each $\mathrm{N}$ supply. So, genotypic variation in NAE has to be compared at a similar shoot mass; otherwise, the difference would be trivial.

2. The $\mathrm{N}$ dilution process implies that $\mathrm{dN}_{\mathrm{upt}} / \mathrm{dW}_{\mathrm{sh}}$ decreases as shoot mass increases, so that NCE $\left(\mathrm{dW}_{\mathrm{sh}} / \mathrm{dN}_{\text {upt }}\right)$ increases as shoot mass increases. Consequently, the NCE of different genotypes has also to be compared at a similar shoot mass; otherwise, the difference observed would be obvious with a larger crop having always a higher NCE than a smaller one.

An expression for plant $\mathrm{N}$ concentration $(\% \mathrm{~N})$ is readily obtained from Eq. (7) by dividing both sides by $\mathrm{W}_{\text {sh }}$ and the right side by 10 for having plant $\mathrm{N}$ concentration in percent with $\mathrm{W}_{\text {sh }}$ in $\mathrm{tha}^{-1}$ :

$\% \mathrm{~N}=\mathrm{a} / 10 \times\left(\mathrm{W}_{\mathrm{sh}}\right)^{\mathrm{b}-1}$

Given that $\mathrm{b}<1$, the $\% \mathrm{~N}$ decreases with increasing $\mathrm{W}_{\text {sh }}$, which defines a "N dilution curve" over a range of $\mathrm{W}_{\mathrm{sh}}$. Lemaire et al. (2008) have shown, following the assumptions of Caloin and $\mathrm{Yu}$ (1984), that $\mathrm{N}$ dilution curves are consistent with the relative size of two major plant compartments:

1. $\mathrm{W}_{\mathrm{m}}$, the "metabolic compartment" of plant tissues directly associated with photosynthesis and growth processes, with a high $\mathrm{N}$ concentration: $\% \mathrm{~N}_{\mathrm{m}}$

2. $\mathrm{W}_{\mathrm{s}}$, the "structural compartment" of plant tissues associated with plant architecture and hydraulic conductivity, with a low $\mathrm{N}$ concentration: $\% \mathrm{~N}_{\mathrm{s}}$

$\mathrm{W}_{\mathrm{sh}}=\mathrm{W}_{\mathrm{m}}+\mathrm{W}_{\mathrm{s}}$

They postulated that the absolute growth rate $\left(\mathrm{dW}_{\mathrm{sh}} / \mathrm{dt}\right)$ of a crop should be, by definition, proportional to its metabolic compartment $\left(\mathrm{W}_{\mathrm{m}}\right)$ : 

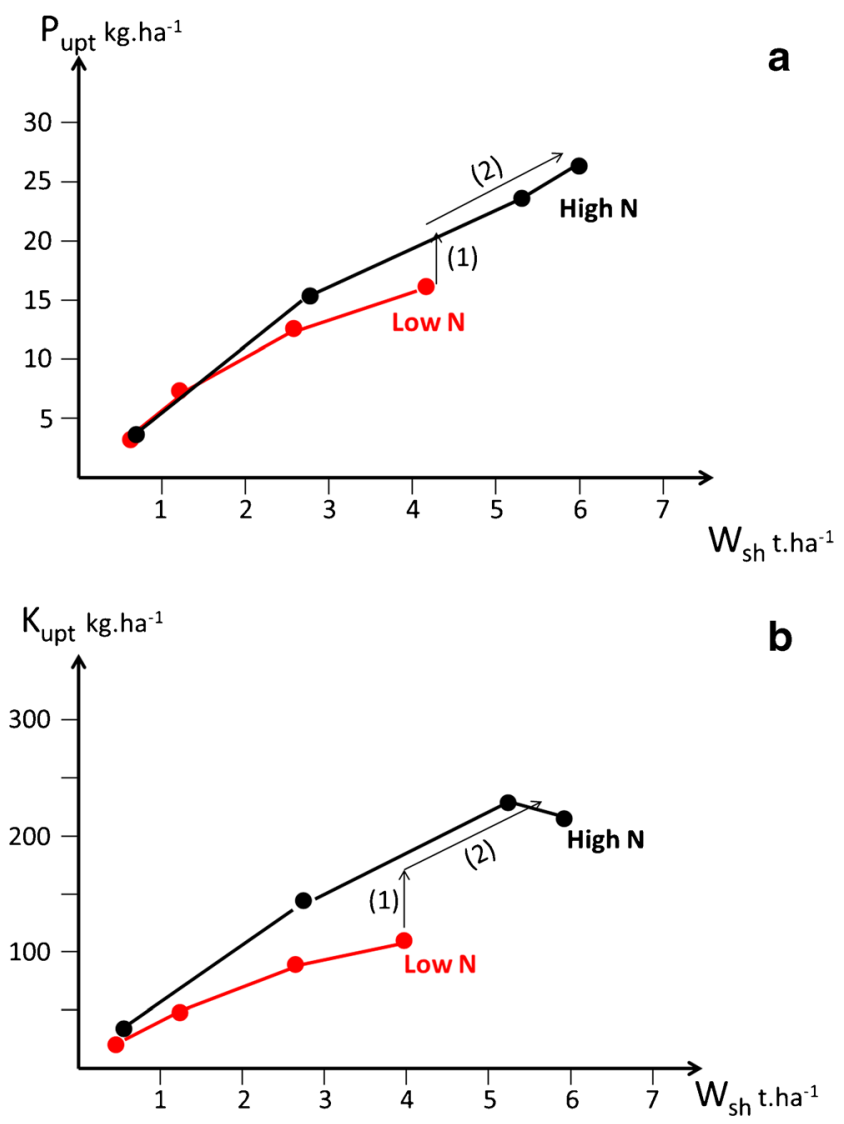

Fig. 4 Trajectories of $\mathrm{N}$ uptake as a function of shoot mass accumulation $\left(\mathrm{W}_{\text {sh }}\right)$ for different steady-state levels of $\mathrm{N}$ supply: $\mathrm{N}$ soil ( $\mathrm{N}$ supply only from the soil without any $\mathrm{N}$ fertilizer application, $\mathrm{N}$ fert ( $\mathrm{N}$ supply with a limiting $\mathrm{N}$ fertilization rate; $\mathrm{N}$ crit. ( $\mathrm{N}$ supply with a minimum $\mathrm{N}$ application for achieving maximum shoot mass accumulation); and $\mathrm{N}$ max ( $\mathrm{N}$ supply with a supra-optimum $\mathrm{N}$ fertilizer rate). Adapted from Gastal et al. (2014)

$\mathrm{dW}_{\mathrm{sh}} / \mathrm{dt}=\mathrm{k} \times \mathrm{W}_{\mathrm{m}}$

Rearranging Eq. (11) and dividing both sides by $\mathrm{W}_{\text {sh }}$ gives a relationship between the fraction of the metabolic component and the relative growth rate:

$\mathrm{W}_{\mathrm{m}} / \mathrm{W}_{\mathrm{sh}}=1 / \mathrm{k} \times 1 / \mathrm{W}_{\mathrm{sh}} \times\left(\mathrm{dW}_{\mathrm{sh}} / \mathrm{dt}\right)$

Plant $\mathrm{N}$ concentration $(\% \mathrm{~N})$ can be calculated from the relative contribution of the two compartments, $\mathrm{W}_{\mathrm{m}}$ and $\mathrm{W}_{\mathrm{s}}$, to the plant shoot mass $\left(\mathrm{W}_{\mathrm{sh}}\right)$ according to Eq. (10):

$\% \mathrm{~N}=1 / \mathrm{W}_{\mathrm{sh}} \times\left[\left(\% \mathrm{~N}_{\mathrm{m}} \times \mathrm{W}_{\mathrm{m}}\right)+\left(\% \mathrm{~N}_{\mathrm{s}} \times \mathrm{W}_{\mathrm{s}}\right)\right]$

Using Eqs. (12) and (13) gives

$$
\begin{aligned}
\% \mathrm{~N}= & {\left[1 / \mathrm{k} \times 1 / \mathrm{W}_{\mathrm{sh}} \times\left(\% \mathrm{~N}_{\mathrm{m}}-\% \mathrm{~N}_{\mathrm{s}}\right) \times \mathrm{dW} \mathrm{W}_{\mathrm{sh}} / \mathrm{dt}\right] } \\
& +\% \mathrm{~N}_{\mathrm{s}}
\end{aligned}
$$

Caloin and Yu (1984) proposed that the metabolic component $\mathrm{W}_{\mathrm{m}}$ is linked to the whole plant shoot mass $\left(\mathrm{W}_{\mathrm{sh}}\right)$ by an allometric relationship:
$\mathrm{W}_{\mathrm{m}}=\mathrm{c} \times\left(\mathrm{W}_{\mathrm{sh}}\right)^{\alpha}$

Substituting $\mathrm{W}_{\mathrm{m}}$ from Eq. (11) into Eq. (15) gives

$\mathrm{dW}_{\mathrm{sh}} / \mathrm{dt}=\mathrm{kc} \times\left(\mathrm{W}_{\mathrm{sh}}\right)^{\alpha}$

Including Eq. (16) within Eq. (14) gives

$\% \mathrm{~N}=\left[\mathrm{c} \times\left(\% \mathrm{~N}_{\mathrm{m}}-\% \mathrm{~N}_{\mathrm{s}}\right) \times \mathrm{W}_{\mathrm{sh}}{ }^{\alpha-1}\right]+\% \mathrm{~N}_{\mathrm{s}}$

Lemaire and Gastal (1997) showed that the difference between Eqs. (9) and (17), due to the existence of an asymptote different of 0 on Eq. (17) representing the minimum $\mathrm{N}$ concentration in structural tissues was only sensible for $\mathrm{W}_{\mathrm{sh}}>$ $20 \mathrm{t} \mathrm{ha}^{-1}$, and that under this value, Eq. (9) could be considered as an acceptable approximation of the $\mathrm{N}$ dilution process.

Lemaire et al. (2008) showed that it was possible to determine the critical $\mathrm{N}$ dilution curves according to Eq. (9) corresponding to the minimum $\mathrm{N}$ concentration for achieving the maximum crop mass accumulation. Critical $\mathrm{N}$ dilution curves have been estimated for a large number of crop species. Using these critical $\mathrm{N}$ dilution curves (Eq. 9), it is possible, for each crop and stage during its vegetative phase, to determine a Nitrogen Nutrition Index (NNI) as the ratio between its actual $\mathrm{N}$ concentration $\left(\% \mathrm{~N}_{\mathrm{a}}\right)$ and the critical $\mathrm{N}$ concentration $\left(\% \mathrm{~N}_{\mathrm{c}}\right)$ corresponding to the actual crop mass $\left(\mathrm{W}_{\mathrm{sh}}\right)$ of the crop. The NNI is an agronomically relevant trait for the diagnosis of crop $\mathrm{N}$ nutrition status and other applications (Box 3).

Box 3 Applications of the Nitrogen Nutrition Index (NNI)

NNI has been shown to be a good predictor of the relative crop mass production for forage and grassland species (Gastal et al. 2014). Moreover, NNI is associated with grain yield in maize (Plénet and Cruz 1997; Ziadi et al. 2008b), wheat (Justes et al. 1997; Ziadi et al. 2010a; Hoogmoed et al. 2018), barley and rice (Zhao et al. 2014; Tahir Ata-Ul-Karim et al. 2016), rapeseed (Colnenne et al. 1998), sunflower (Debaeke et al. 2012), and with potato tuber yield (Bélanger et al. 2001c).

The NNI can be used for four main purposes: (i) for an early-season diagnosis to guide top-dressing $\mathrm{N}$ in rainfed wheat (Neuhaus and Sadras 2018); (ii) as a forensic tool for benchmarking actual crop yield (Hoogmoed et al. 2018); (iii) as a reference for calibrating simpler and less time consuming diagnostic tools such as leaf chlorophyll (Ziadi et al. 2008c), leaf $\mathrm{N}$ concentration (Farrugia et al. 2004; Ziadi et al. 2009, 2010b), petiole nitrates (Bélanger et al. 2003), stem base nitrates (Justes et al. 1997), and remote sensing indices (Cossani and Sadras 2018); and (iv) in combination with prognostic $\mathrm{N}$ fertilization tools within decision support systems for a better adjustment of crop $\mathrm{N}$ fertilization management to actual crop demand (Ravier et al. 2018). Using the NNI requires destructive measurements of actual crop mass and its $\mathrm{N}$ concentration that are time consuming at farm level or indirect estimation with remote sensing (Baret and Fourty 1997; Cossani and Sadras 2018) that allow high spatial and temporal resolution. Currently, fertilizer recommendations for wheat in large areas of Western Australia rely on NNI derived from destructive sampling and laboratory analysis (Neuhaus and Sadras 2018). Estimation of NNI of rice, wheat, and maize crops through remote sensing is now developing widely across several regions in China for $\mathrm{N}$ fertilization decisions (Peng et al. 2010; Yao et al. 2010; Zhao et al. 2016). 
Many crop simulation models ignore these fundamental allometries and simulate dry matter allocation (e.g., leaf and stem mass fractions and specific leaf area used to estimate LAI) as a function of plant phenology (Jones et al. 2003; Keating et al. 2003). Using an ontogenetic scale may be convenient for modeling purposes because phenological development and the accumulation of dry mass and $\mathrm{N}$ are all related with crop age. Phenology-dependent changes in allocation of dry mass between metabolic and structural tissues, chiefly stem-leaves during the phase of stem elongation, explain some of the scatter in nutrient-dry mass curves (Hoogmoed and Sadras 2018). For this reason, dilution curves relating critical plant $\mathrm{N}$ concentration and phenological stage have been advanced for cereals (Angus and Moncur 1985; Zhao et al. 2014). However, fitting curves to development stages is not justified because the independent variable is nominal rather than quantitative, and the relation between critical nitrogen concentration and crop mass has a stronger theoretical background (Hoogmoed and Sadras 2018, Hoogmoed et al. 2018; Ratjen et al. 2018). Moreover, even if the onset of stem internode elongation is a key developmental step that influences dry mass partitioning between leaf and stem, the leaf area ratio (LAR) (Eq. 6) seems more physiologically relevant to capture metabolic vs structural partitioning than the leaf/stem ratio alone. As shown by Ratjen et al. (2018), LAR is the product of L/S and specific leaf area (SLA), and these two traits are closely linked: when stem internodes elongate and L/S declines, the SLA increases for the leaves growing progressively into the well-illuminated layer of the canopy. The STICS model (Brisson et al. 1998) and the CATIMO model for forage grasses (Bonesmo and Bélanger 2002) use $\mathrm{N}$ dilution curves related to crop mass to assess $\mathrm{N}$ stress and to calculate crop $\mathrm{N}$ requirements

Lemaire et al. (2007) showed an interesting correspondence in the two scaling coefficients for LAI ( $\alpha$ in Eq. 5) and $\mathrm{N}$ uptake ( $b$ in Eq. 7). As shown in Table 1, these two coefficients are conserved over a wide range of species. Consequently, if we accept that $\alpha$ is not different to $b$, a proportionality between $\mathrm{N}$ uptake and crop LAI is readily obtained and defined by the constant ratio $a / k$

$\mathrm{N}_{\text {upt }}=\mathrm{a} / \mathrm{k} \times$ LAI

This proportionality between $\mathrm{N}$ uptake and LAI has been observed empirically for several crops and particularly for cereals (Sylvester-Bradley et al. 1990; Grindlay et al. 1993; Grindlay, 1997). The $\mathrm{N}_{\text {upt }}$-LAI proportionality of Eq. (18) leads to an emergent description for comparing $\mathrm{N}$ use among species and genotypes. The coefficient $a / k$ vary across species for two main reasons: (i) morphological differences related to the "leafiness" coefficient $k$ and (ii) metabolic differences for coefficient $a$ between $\mathrm{C} 3$ and $\mathrm{C} 4$ species (Table 1). Species with "grass type" morphologies tend to have greater $a / k$ and greater $\mathrm{N}$ uptake with increasing LAI than their non-grass counterparts.

\subsubsection{Extension to $P$ and $K$}

A similar allometry between P uptake (Pupt) or K uptake (Kupt) and shoot mass accumulation as described above for $\mathrm{N}$ was reported from several studies on grasslands (Salette 1990; Salette and Huché 1991; Duru et al. 1992):

$P_{\text {upt }}=a_{P} \times\left(W_{s h}\right)^{b_{P}}$

$K_{u p t}=a_{K} \times\left(W_{s h}\right)^{b_{K}}$

where $a$ is nutrient uptake necessary for producing a shoot mass of $1 \mathrm{tha}^{-1}, b$ is the scaling coefficient, and subscripts indicate nutrient $\mathrm{P}$ and $\mathrm{K}$. Critical $\mathrm{P}_{\text {upt }}$ and $\mathrm{K}_{\text {upt }}$ curves, corresponding to the minimum $\mathrm{P}$ and $\mathrm{K}$ uptake necessary to achieve maximum shoot mass $\left(\mathrm{W}_{\mathrm{sh}}\right)$, can be determined from field studies with different supplies of $\mathrm{P}$ and $\mathrm{K}$.

Similar to the calculation for N, the plant $\mathrm{P}$ and $\mathrm{K}$ concentrations as a function of $\mathrm{W}_{\mathrm{sh}}$ can be calculated:

$\% P=\frac{a_{P}}{10} \times\left(W_{s h}\right)^{b_{P}-1}$
$\% K=\frac{a_{K}}{10} \times\left(W_{s h}\right)^{b_{K}-1}$

These allometric equations first established empirically on grasslands and forage crops, illustrate a dilution in $\mathrm{P}$ and $\mathrm{K}$ concentration as $\mathrm{W}_{\mathrm{sh}}$ increases. They are in line with the model developed by Greenwood and Stone (1998) and Greenwood and Karpinets (1997) on the dynamics of K uptake in vegetable crops that shows a decline in plant $\% \mathrm{~K}$ with increasing shoot mass. In the same way, the model developed by Greenwood et al. (2001) for P uptake shows that the plant $\% \mathrm{P}$ needed for maximum plant growth decreases with increasing shoot mass. Several studies have since shown the decrease in plant \% P with the increasing shoot mass of maize (Ziadi et al. 2007), spring wheat (Ziadi et al. 2008a; Bélanger et al. 2015a), and canola (Bélanger et al. 2015b).

The dynamic of $\mathrm{P}$ and/or $\mathrm{K}$ uptake as described by Eqs. (19-20) depend on the level of $\mathrm{N}$ supply in two ways as illustrated in Fig. 5: (1) through an increase in the $\mathrm{P}$ and $\mathrm{K}$ uptake capacity of plants at a similar crop mass and (2) through an increase in crop mass accumulation due to the effect of the increasing $\mathrm{N}$ supply.

The second effect can be simply explained by the increased $\mathrm{P}$ and $\mathrm{K}$ demand resulting from a higher crop growth rate and would correspond to a feedback control of $\mathrm{P}$ and $\mathrm{K}$ absorption rate similar to that well demonstrated for $\mathrm{N}$ (see above) and already postulated for $\mathrm{P}$ and $\mathrm{K}$ (Scaife 1994). The first effect is unexpected and would require a more fundamental 


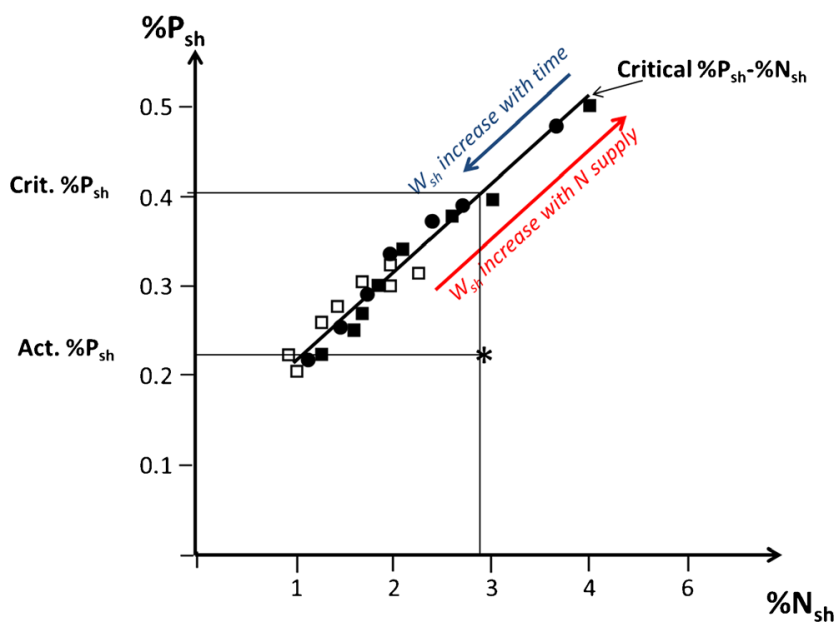

Fig. 5 Illustration of the effect of $\mathrm{N}$ supply on the allometry between $\mathrm{P}$ uptake (a) and K uptake (b) and shoot mass for natural grasslands. This effect can be decomposed into two parts: (1) an increase in $\mathrm{P}$ or K uptake at a similar shoot mass and (2) an increase in $\mathrm{P}$ and $\mathrm{K}$ uptake associated to the increment in shoot mass. Adapted from Duru et al. (1992)

understanding for explaining the positive effect of increased $\mathrm{N}$ supply on $\mathrm{P}$ and $\mathrm{K}$ absorption.

Several authors suggest using the $\mathrm{P} / \mathrm{N}$ ratio for the diagnosis of P nutrition of crops (Güsewell et al., 2003; Drenovsky and Richards, 2004; Sadras, 2006; Greenwood et al. 2008). The allometric relationships of $\mathrm{P}$ and $\mathrm{N}$ with shoot mass (\%P$\mathrm{W}_{\mathrm{sh}}$ and $\% \mathrm{~N}-\mathrm{W}_{\mathrm{sh}}$ ) lead to the relationship between $\% \mathrm{P}$ and $\% \mathrm{~N}$ as illustrated in Fig. 6, highlighting the variation in the $\% \mathrm{P}: \% \mathrm{~N}$ ratio. This ratio increases as $\% \mathrm{~N}$ decreases as a consequence of either (i) the dilution of $\mathrm{N}$ by increasing crop mass or (ii) a decrease in $\mathrm{N}$ supply. Consequently, the $\% \mathrm{P} / \% \mathrm{~N}$ ratio cannot be used alone as an unequivocal index of the $\mathrm{P}$ nutrient status of a crop.

Several studies have since shown that the $\% \mathrm{P} / \% \mathrm{~N}$ ratio varies with shoot mass (Ziadi et al., 2007; Greenwood et al., 2008; Bélanger et al. 2017) and the crop N status. Under nonlimiting N, Greenwood et al. (2008) quantified the relationship between the $\% \mathrm{~N} / \% \mathrm{P}$ ratio and shoot mass for several annual crops and this relationship was later confirmed for perennial forage grasses (Bélanger et al. 2017). More research is needed to understand the physiology underlying the stoichiometric relationships of nutrients in plants, and its agronomic and ecological consequences (Agren 2004; Niklas et al. 2005; Reich et al. 2010).

Similar relationships between $\% \mathrm{~K}$ and $\% \mathrm{~N}$ were observed for grasslands species and natural grasslands (Salette and Huché 1991; Duru et al. 1992). As a result, critical \%P-\%N and $\% \mathrm{~K}-\% \mathrm{~N}$ relationships have been established corresponding to non-limiting $\mathrm{P}$ and $\mathrm{K}$ supplies that allow a crop $\mathrm{P}$ and $\mathrm{K}$ nutrition diagnosis by calculating a nutrition index of $\mathrm{P}$ (PNI) or $\mathrm{K}(\mathrm{KNI})$ as the ratio between actual $(\% \mathrm{~Pa}, \% \mathrm{Ka})$ and critical $(\% \mathrm{Pc}, \% \mathrm{Kc})$ concentrations as illustrated in Fig. 6 for P.
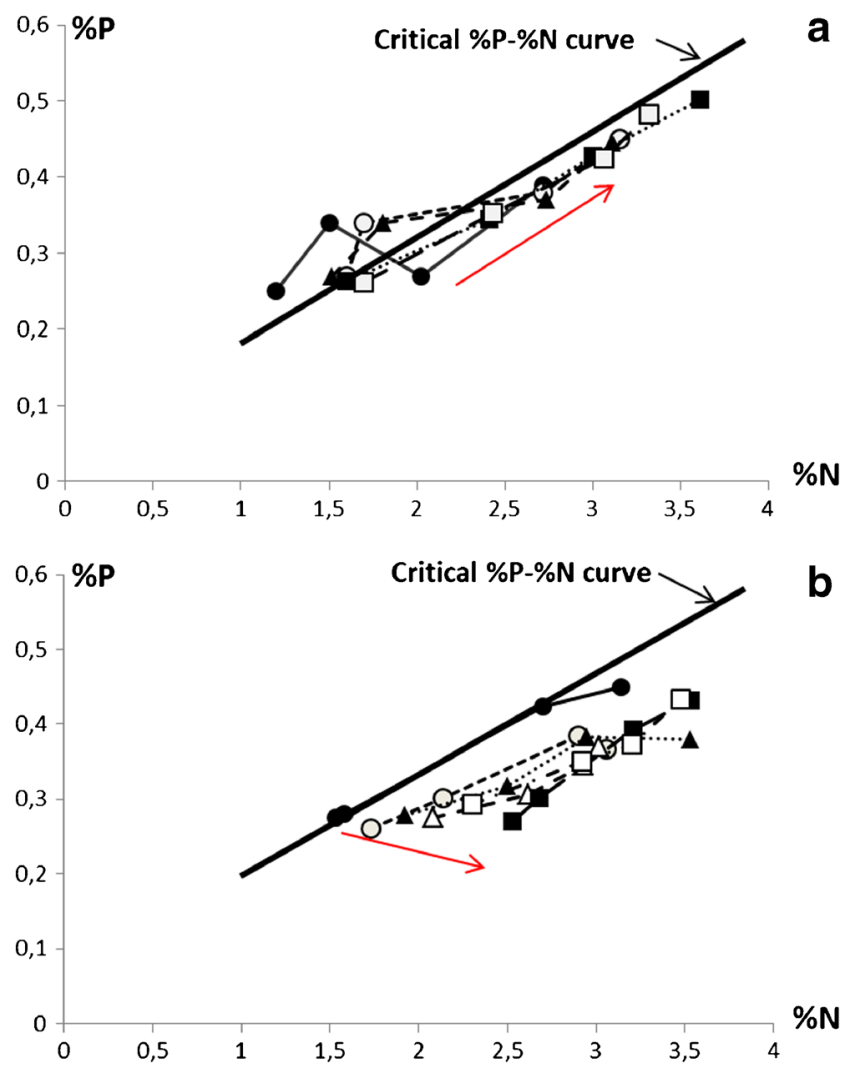

Fig. 6 Relationship between $\mathrm{P}$ and $\mathrm{N}$ concentrations in shoots $\left(\% \mathrm{P}_{\mathrm{sh}}\right.$ and $\% \mathrm{~N}_{\mathrm{sh}}$ expressed in per cent of dry matter) for different natural grasslands in spring under non-limiting $\mathrm{P}$ supply conditions and having received different levels of $\mathrm{N}$ supply at the end of winter: white square no $\mathrm{N}$ application; black square100 $\mathrm{kgN} \mathrm{ha}^{-1}$; black circle $150 \mathrm{kgN} \mathrm{ha}^{-1}$. The regression line $\left[\% \mathrm{P}_{\mathrm{sh}}=\left(0.091 \times \% \mathrm{~N}_{\mathrm{sh}}\right)+0.133 ; \mathrm{R}^{2}=0.97\right]$ represents the "critical $\% \mathrm{P}_{\text {sh." }}$. Variations in $\% \mathrm{~N}_{\mathrm{sh}}$ are due to either (i) variation in shoot mass $\left(\mathrm{W}_{\text {sh }}\right)$ due to different $\mathrm{N}$ supplies and (ii) a $\mathrm{N}$ dilution effect associated to biomass accumulation with time. A $\mathrm{P}$ nutrition index (PNI) can then be calculated as $\mathrm{PNI}=\left(\right.$ Act. $\left.\% \mathrm{P}_{\text {sh }}\right) /\left(\right.$ Crit. $\left.\% \mathrm{P}_{\text {sh }}\right)$ for estimating the $\mathrm{P}$ nutrition level of a given crop. Adapted from Salette and Huché (1991)

Using the relationship between $\mathrm{N}$ and $\mathrm{P}$ concentrations, crop nutrition can be examined in more detail. The results from Ziadi et al. (2008a, b, c) for maize crops grown on different soils in eastern Canada are used to illustrate the interaction between $\mathrm{P}$ and $\mathrm{N}$ concentration (Fig. 7). Under high soil $\mathrm{P}$, increasing crop $\mathrm{P}$ demand due to increased $\mathrm{N}$ supply and crop mass accumulation can be satisfied and results in an increase of both $\% \mathrm{P}$ and $\% \mathrm{~N}$. In a low soil $\mathrm{P}$, however, the increased $\mathrm{P}$ demand due to increased $\mathrm{N}$ supply cannot be satisfied in the same proportion, resulting in a disconnection between $\% \mathrm{P}$ and $\% \mathrm{~N}$ that reflect a crop $\mathrm{P}$ deficiency induced by $\mathrm{N}$ supply. Kamprath (1987) reported also an enhanced $\mathrm{P}$ concentration of maize crop resulting from $\mathrm{N}$ fertilization in soil with high $P$ availability.

Similarly, Duru and Ducrocq (1997) showed that, for natural grasslands, $\mathrm{N}$ fertilization in absence of $\mathrm{P}$ fertilization could aggravate the $\mathrm{P}$ deficiency, while fertilization with both 


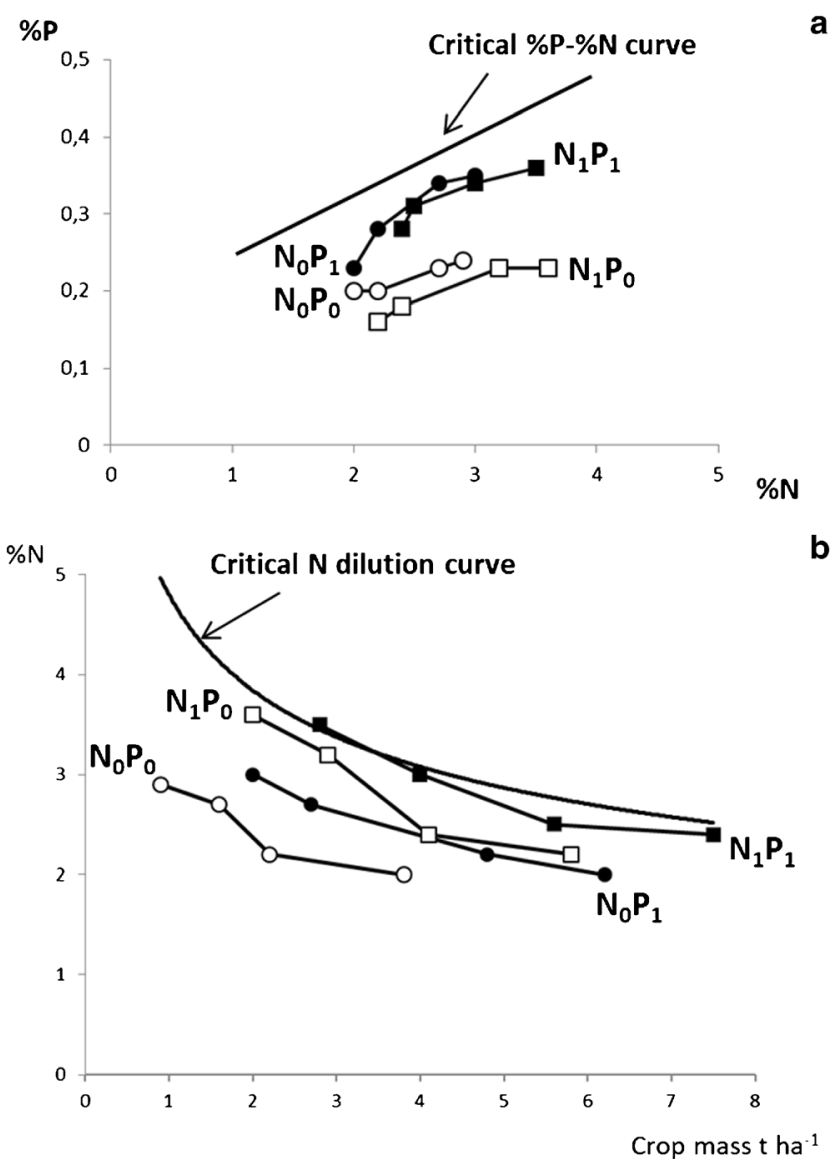

Fig. 7 Shift in the $\% \mathrm{P}-\% \mathrm{~N}$ relationship according to the $\mathrm{N}$ supply of a maize crop in conditions of high (a) or low (b) soil P availability in eastern Canada. The red arrow in a indicates the positive shift in both $\% \mathrm{P}$ and $\% \mathrm{~N}$ as $\mathrm{N}$ supply increases, while the arrow in $\mathbf{b}$ indicates a negative shift in $\% \mathrm{P}$ associated with a positive shift in $\% \mathrm{~N}$. The $\mathrm{N}$ supply treatments were 0 (dark circles), 40 (open circles), 80 (dark triangles), 120 (open triangles), 160 (dark squares), and $200 \mathrm{kgN} / \mathrm{ha}$ (open squares). The critical $\% \mathrm{P}-\% \mathrm{~N}$ curve is $\% P=0.107 \% \mathrm{~N}+0.094$ as determined by Ziadi et al. (2008a, b, c). Redrawn from Ziadi et al. (2008a, $b, c)$

nutrients increased both $\% \mathrm{P}$ and $\% \mathrm{~N}$ as illustrated in Fig. 8a. Conversely, $\mathrm{P}$ fertilization can lead to an increase in $\% \mathrm{~N}$ at a similar plant mass that corresponds to an increase in the crop $\mathrm{N}$ nutrition status (Fig. 8b). Hence, as demonstrated by Duru and Ducrocq (1997), the effect of P supply on forage production is the result of two complementary processes: (i) a direct response to the $\mathrm{P}$ supply and (ii) an indirect effect of improved crop $\mathrm{P}$ nutrition that enhances $\mathrm{N}$ acquisition and the crop $\mathrm{N}$ nutrition status.

Those relationships based on the concomitant dilution of $\mathrm{N}, \mathrm{P}$, and $\mathrm{K}$ in increasing shoot mass during crop growth provide tools for assessing their status by calculating nutrition indices and, indirectly, their soil availability. Contrary to $\mathrm{N}$ for which an in-season diagnostic test and remedial actions are possible, plant-based tests based on the nutrition indices of $\mathrm{P}$ and $\mathrm{K}$ might have more potential to be used a posteriori to adjust fertilization for the following growing season.
In a recent meta-analysis of wheat yield response to $\mathrm{N}, \mathrm{P}$, and K fertilizer applications, Duncan et al. (2018) highlighted general and significant interactions among nutrients, and how the crop capacity to uptake a given element is enhanced as availability of other elements increases. Consequently, $\mathrm{N}$ use efficiency increases as $\mathrm{P}$ and $\mathrm{K}$ supplies increase. The allometry approach developed above allows the capture of these interactions and provides the opportunities for developing diagnostic methods for a well-balanced crop nutrition.

\section{Further research and applications}

\subsection{Limits of the allometric approach to crop nutrition}

The allometric analysis of crop $\mathrm{N}$ nutrition is based on the simplification that $\mathrm{N}$ is allocated to two functions and compartments in vegetative plants: (i) plant growth, as driven by light harvesting and photosynthesis within N-rich leaf parenchyma tissues and (ii) plant architecture, mechanical resistance, and hydraulic conductivity associated with N-poor fiber and vascular tissues. The general allometry relating these two compartments leads to the dilution of nitrogen with crop growth. Nitrogen mobilized from older leaves in shaded parts of the canopy to younger leaves in the top of the canopy further contributes to the dilution of $\mathrm{N}$. The trade-off in investment between alternative compartments and functions is bounded by biophysical constraints at the canopy level, hence the limited variation in allometries among species within $\mathrm{C} 3$ and $\mathrm{C} 4$ plant types. Allometry thus describes fundamental "emerging properties" with implications for agronomic practices to improve crop nutrition and for phenotyping approaches to improve $\mathrm{N}$ use efficiency.

The concentration of $\mathrm{N}$ in whole plants is unsuitable in itself to quantify the crop nutrient status for both diagnostic and phenotyping applications because the critical $\mathrm{N}$ concentration for achieving maximum growth depends on plant and canopy size and, particularly, crop mass. Hence, the determination of the crop $\mathrm{N}$ status through measurements of plant $\mathrm{N}$ concentration requires $\mathrm{N}$ dilution curves accounting for the mass-dependent critical $\mathrm{N}$ concentration. The NNI based on a mass-dependent critical N concentration allows the comparison of plant $\mathrm{N}$ concentration at a similar crop mass. The need to account for nutrient-biomass allometry also applies to $\mathrm{P}$ and $\mathrm{K}$.

This mass-dependency of the critical plant $\mathrm{N}$ concentration is the consequence of a general pattern of dry matter allocation in plants within canopies. The dry matter allocation to structural and supporting tissues for positioning leaf areas within the well-illuminated upper layers of canopies increases as crops grow. This process of shade avoidance can then be encapsulated within a general allometry between LAI and crop mass. Consequently, attempts to use some plant morphological traits such as the leaf/stem ratio or SLA for phenotyping 


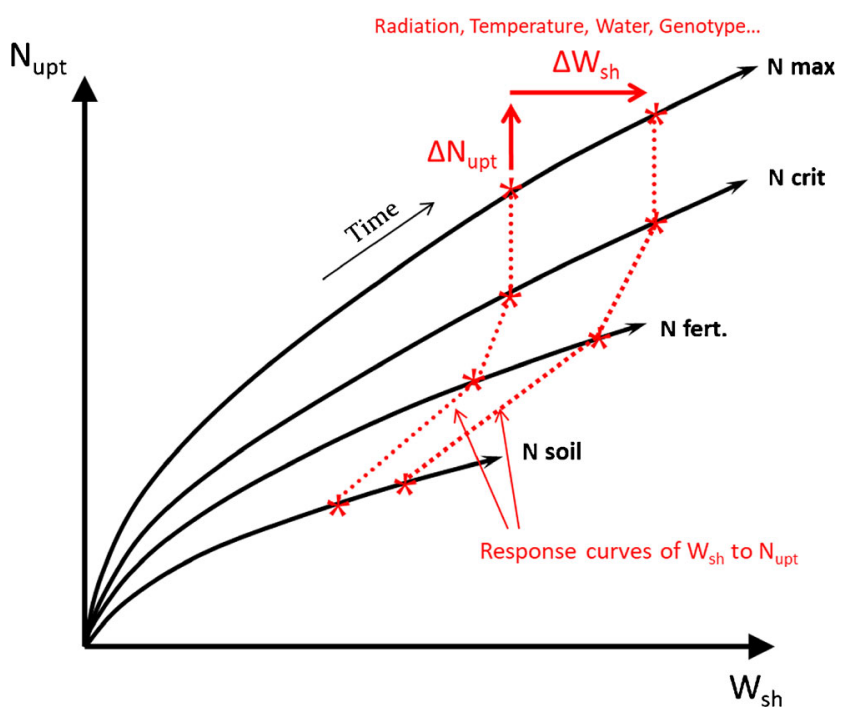

Fig. 8 Nitrogen-phosphorus interactions in natural grasslands receiving a factorial combination of high applications of $\mathrm{N}$ (squares) and $\mathrm{P}$ (dark symbols) and no application of $\mathrm{N}$ (circles) and $\mathrm{P}$ (open symbols). a Effects of the $\mathrm{N}$ and $\mathrm{P}$ supplies on shoot $\mathrm{P}$ and $\mathrm{N}$ concentration ( $\mathrm{P} \%$, $\% \mathrm{~N}$ ); the line represents the critical $\mathrm{P}$ concentration: $\% \mathrm{P}_{\mathrm{c}}=0.065 \% \mathrm{~N}_{\mathrm{c}}+$ 015 as determined by Duru and Thellier (1997). b Effects on the $\mathrm{N}$ and $\mathrm{P}$ supplies on shoot $\mathrm{N}$ concentration (N\%); the line represents the critical $\mathrm{N}$ dilution curves for C3 grasses species (Lemaire and Gastal 1997). Adapted from Duru and Ducrocq (1997)

species or genotypes (Lavorel and Garnier 2002) appears to be of limited generic value as demonstrated by Ratjen et al. (2018).

We have shown that allometric relationships between nutrients and crop mass are partially associated with competition for light among individual plants within the canopy. Nitrogen dilution curves are density-dependent (Seginer 2004), and they reach an asymptotic value only for dense canopies intercepting most of incident light. For crops with a low sowing or planting density or with a non-uniform spatial repartition, the use of critical $\mathrm{N}$ dilution curves requires a different measure than shoot mass per unit of soil area, which could possibly be shoot mass per plant or shoot mass per unit of row length. Moreover, the use of NNI should be restricted to the vegetative period with $\mathrm{LAI}>1$. During reproduction in annual grain crops, the LAI- $\mathrm{W}_{\mathrm{sh}}$ allometry is broken and the $\mathrm{N}$ dilution process is disturbed by (i) leaf senescence and $\mathrm{N}$ remobilization from leaves to grains and (ii) by the equilibrium between starch and protein accumulation during grain filling. This last process leads to a large variation in $\mathrm{N}$ dilution rates across species according to the equilibrium between carbohydrates, lipids, and proteins accumulating in grains. For crops such as maize or sorghum that accumulate proportionally more starch than protein in grains, there is an acceleration of the $\mathrm{N}$ dilution during grain filling (Plénet and Cruz 1997). In soybean, however, more proteins are accumulated in grains and there is tendency for an attenuation of the $\mathrm{N}$ dilution process (Divito et al. 2016). For grain crops, the NNI method for crop phenotyping after anthesis must be used with caution and would require more specific analyses.

The allometric approach also applies to $\mathrm{P}$ and $\mathrm{K}$ but theory for these two elements are not so well established as for $\mathrm{N}$ and data are lagging. More precise information concerning the compartmentalization of these elements within plants is necessary. Models of nutrient allometry could be extended for integrated N-P-K diagnosis that captures the nutrient interactions in the context of co-limitation and stoichiometry. The return from investments in precision agriculture and crop phenotyping, where the dominant focus is on cheaper and better data, would benefit for a more exhaustive theoretical framework of the allometric relationships related to $\mathrm{P}, \mathrm{K}$. The extension of the theory to crop $\mathrm{S}$ nutrition seems promising (Reussi Calvo et al. 2011) but more extensive research is necessary for developing this aspect.

\subsection{Applications for fertilizer management}

The theory developed above on allometry opens perspectives for in situ diagnosis of crop nutrient status. For N, an early crop diagnosis to guide top-dressing is then possible for applying $\mathrm{N}$ fertilizer only when necessary. The uncertainty linked to the prognosis approach under unpredictable conditions should then be partially solved. A major difficulty in using the NNI at the farm level, however, is the need to determine the actual crop mass and its $\mathrm{N}$ concentration. For this reason, it may be more practical to use the NNI as a reference for calibration of simpler plant diagnosis procedures (e.g., leaf chlorophyll measurements, petiole nitrate concentration) or remote sensing measurements (see Box 3). Then, the monitoring of crop $\mathrm{N}$ status along the crop growth cycle could be included within crop fertilization management procedures for farmer's decisions on the timing and rate of $\mathrm{N}$ fertilizer application. (Ravier et al. 2018).

$\mathrm{P}$ and $\mathrm{K}$ fertilization management is commonly based on soil tests and prognostics on soil nutrient availability for plants. Annual estimates of crop P and K status via PNI and KNI can complement soil balance approaches. Moreover, mapping crop PNI and KNI at landscape or regional scale could provide valuable complementary information for soil survey systems.

\subsection{Perspectives for crop phenotyping}

Genotype-environment-management interactions are of central interest for agronomists and plant breeders. The statistical analysis of responses of crop yield to nominal treatments (e.g., high vs low $\mathrm{N}$ ) provides little information. Although the concepts presented above have been established for over two decades, many papers still report results with incomplete or inadequate quantification of the crop nutrition status (Sadras and Lemaire, 2014). 
The NNI, and also PNI and KNI in some circumstances, should be considered indispensable co-variables for interpreting field data where the focus is comparisons of genotypes and practices. Most of the crop management practices such as date or density of sowing or plantation, tillage, or weeding methods are susceptible to influence plant $\mathrm{N}$ nutrition as well as other plant traits. It is, therefore, important to check the crop NNI for separating the direct effect of these management practices from their indirect effect through plant $\mathrm{N} \mathrm{nu-}$ trition. Similarly, any change in environmental conditions (e.g., temperature, radiation, rainfall, soil water content) directly affecting plant growth dynamics and, then, crop $\mathrm{N}$ demand, could also affect soil $\mathrm{N}$ availability and, therefore plant NNI. Moreover, comparing different genotypes or cultivars having different growth patterns and then different crop $\mathrm{N}$ demand can lead to different crop NNI under a given soil N supply condition. So, parameters deduced from the allometry approach of crop nutrition should help in a more comprehensive interpretation of agronomic and plant breeding datasets. Moreover, with the help of crop models, these allometry parameters should be used for genotype prototyping in future plant breeding programs.

\section{Conclusions}

Owing to the degradation of the environment caused by overfertilization in some cropping systems, and the depletion of soil organic matter in systems with negative nutrient balance, it is urgent to refine our conceptual and practical tools for nutrient management. This review highlights that (i) crop nutrient uptake is co-regulated by soil nutrient availability and plant demand, (ii) nutrient concentration is allometrically linked to shoot biomass, (iii) nutrient-biomass allometry is density-dependent, and (iv) crops respond to the interactions between N, P, and K. So, a more integrated vision of crop nutrition is necessary that links supply and demand of nutrients, nutrients and biomass, and interactions among nutrients.

Reliable measures of crop nitrogen status for management of crop nutrition require dilution curves that are available for most crops. Dilution curves are needed for P and K. Whereas the NNI, PNI, and KNI are the more robust traits to quantify crop nutrition status, methods based on destructive sampling, and lab analysis are mostly unsuitable to guide management decisions. Instead, these traits are best seen as benchmarks to calibrate other methods that are easier to implement and costeffective.

Phenotyping individual plants or unrealistic arrangements (e.g., single rows) overlooks plant-plant interactions and is therefore bound to bias nutrient-mass relationships as well as partitioning coefficients. Traits commonly used in phenotyping for nutrient-use efficiency include nutrient concentration in plant tissue and nutrient uptake, but these are unreliable when measured in individual plants. Likewise, intra- or inter-specific comparisons of mass-dependent traits such as the leaf/stem ratio or specific leaf area, particularly common in ecology (see Lavorel and Garnier 2002) must be done at a similar shoot mass or leaf area index. Further, the trade-offs between these traits highlight the limited functional meaning when they are analyzed independently.

\section{Compliance with ethical standards}

Conflict of interest The authors declare that they have no conflict of interest.

\section{References}

Agren GI (2004) The C:N:P stoichiometry of autotrophs: theory and observations. Ecol Lett 7:185-191. https://doi.org/10.1111/j.14698137.2010.03214.x

Amir S, Cohen D (1990) Optimal reproductive efforts and the timing of reproduction of annual plants in randomly varying environments. J Theor Biol 147:17-42

Andrews M, Sprent JI, Raven JA, Eady PE (1999) Relationships between shoot to root ratio, growth and leaf soluble protein concentration of Pisum sativum, Phaseolus vulgaris and Triticum aestivum under different nutrient deficiencies. Plant Cell Environ 22:949-958

Angus JF, Grace PR (2017) Nitrogen balance in Australia and nitrogen use efficiency on Australian farms. Soil Res 55:435-450. https://doi. org/10.1071/SR16325

Angus JF, Moncur MW (1985) Models of growth and development of wheat in relation to plant nitrogen. Aust J Agric Res 36:537-544

Anten NPR, Schieving F, Werger MJA (1995) Patterns of light and nitrogen distribution in relation to whole canopy carbon gain in $\mathrm{C} 3$ and C4 mono- and dicotyledonous species. Oecologia 101:504-513

Aphalo PJ, Ballaré CL (1995) On the importance of informationacquiring systems in plant-plant interactions. Funct Ecol 9:5-14

Assuero SG, Mollier A, Pellerin S (2004) The decrease in growth in phosphorus-deficient maize leaves is related to a lower cell production. Plant Cell Environ 27:887-895. https://doi.org/10.1111/j.13653040.2004.01194.x

Ballaré CL, Scopel AL, Sanchez RA (1995) Plant photomorphogenesis in canopies, crop growth and yield. Hort Sci 30:1172-1181

Ballaré CL, Scopel AL, Sanchez RA (1997) Foraging for light: photosensory ecology and agricultural implications. Plant Cell Environ 20:820-825

Baret F, Fourty T (1997) Radioetric estimates of nitrogen status of leaves and canopies. In: Lemaire G, Gastal F (eds) Diagnosis of the nitrogen status in crops. Springer-Verlag, Heidelberg, pp 201-224

Bélanger G, Gastal F, Lemaire G (1992a) Growth analysis of a tall fescue sward fertilized with different rates of nitrogen. Crop Sci 6:13711376

Bélanger G, Gastal F, Warembourg FR (1992b) The effects of nitrogen fertilization and the growing season on carbon partitioning in a sward of tall fescue (Festuca arundinacea Schreb). Ann Bot 70: 239-244

Bélanger G, Gastal F, Warembourg F (1994) Carbon balance on tall fescue: effects of nitrogen and growing season. Ann Bot 74:653659 
Bélanger G, Richards JR, Milburn P, Walker D (1998) Influence of previous cropping practices on the response of spring wheat to applied N. Can J Plant Sci 78:267-273

Bélanger G, Walsh JR, Richards JE, Milburn PH, Ziadi N (2000) Yield response of two potato cultivars to supplemental irrigation and fertilization in New Brunswick. Am J Potato Res 77:11-21. https://doi. org/10.1007/BF02986360

Bélanger G, Michaud R, Jefferson PG, Tremblay GF, Brégard A (2001a) Improving the nutritive value of timothy through management and breeding. Can J Plant Sci 81:577-585. https://doi.org/10.4141/ cjps2013-228

Bélanger G, Walsh JR, Richards JE, Milburn PH, Ziadi N (2001b) Predicting nitrogen fertilizer requirements of potatoes in Atlantic Canada with soil nitrate determinations. Can J Soil Sci 81:535-544

Bélanger G, Walsh JR, Richards JE, Milburn PH, Ziadi N (2001c) Critical nitrogen curve and nitrogen nutrition index for potato in eastern Canada. Am J Potato Res 78:355-364

Bélanger G, Walsh JR, Richards JE, Milburn PH, Ziadi N (2003) Residual soil nitrate after potato harvest. J Environ Qual 32:607-612

Bélanger G, Ziadi N, Pageau D, Grant CA, Högnäsbacka M, Virkajärvi P, Hu ZY, Lu J, Lafond J, Nyiraneza J (2015a) A model of critical phosphorus concentration in the shoot biomass of wheat. Agron J 107:963-970. https://doi.org/10.2134/agronj14.0451

Bélanger G, Ziadi N, Pageau D, Grant CA, Lafond J, Nyiraneza J (2015b) Shoot growth, phosphorus-nitrogen relationships, and yield of canola in response to mineral phosphorus fertilization. Agron J 107: 1458-1464. https://doi.org/10.2134/agronj15.0050

Bélanger G, Ziadi N, Lajeunesse J, Jouany C, Virkajarvi P, Sinaj S, Nyiraneza J (2017) Shoot growth and phosphorus-nitrogen relationship of grassland swards in response to mineral phosphorus fertilization. Field Crops Res 204:31-41. https://doi.org/10.1016/j.fcr. 2016.12.006

Bonesmo H, Bélanger G (2002) Timothy yield and nutritive value by the CATIMO model: I. Growth and nitrogen. Agron J 94:337-345. https://doi.org/10.2134/agronj2002.0337

Boussingault JB (1855) Recherches sur la végétation. De l'action du salpêtre sur le développement des plantes. J Pharm Chim. 3rd series 25:122-131

Bradshaw AD (1965) Evolutionary significance of phenotypic plasticity in plants. Adv Genet 13:115-155

Brisson N, Mary B, Ripoche D, Jeuffroy MH, Ruget F, Nicoullaud B, Gate P, Devienne-Barret F, Antonioletti R, Durr C, Richard G, Beaudoin N, Recous S, Tayot X, Plenet D, Cellier P, Machet JM, Meynard JM, Delecolle R (1998) STICS: a generic model for the simulation of crops and their water and nitrogen balances. I. Theory and parameterization applied to wheat and corn. Agronomie 18: 311-346

Brouwer R (1963) Some aspects of the equilibrium between underground and overground plant parts. Jaarb IBS Wageningen 213:31-34

Caloin M, Yu O (1984) Analysis of the time course change in nitrogen content of Dactylis glomerata L. using a model of plant growth. Ann Bot 54:69-76

Cohen D (1971) Maximising final yield when growth is limited by time or by limiting resources. J Theor Biol 33:299-307

Colnenne C, Meynard JM, Reau R, Justes E, Merrien A (1998) Determination of a critical nitrogen dilution curve for winter oilseed rape. Ann Bot 81:311-317

Connor DJ, Sadras VO (1992) Physiology of yield expression in sunflower. Field Crops Res 30:333-389

Connor DJ, Hall AJ, Sadras VO (1993) Effects of nitrogen content on the photosynthetic characteristics of sunflower leaves. Aust J Plant Physiol 20:251-263

Cossani CM, Sadras VO (2018) Water-nitrogen co-limitation in grain crops. Adv Agron 150:231-274 ISBN: 978-0-12-815175-4

de Wit CT (1992) Resource use efficiency in agriculture. Agric Syst 40: $125-151$
Debaeke P, van Oosterom EJ, Justes E, Champolovier L, Merrien A, Aguizzerabal LAN, Gonzalez-Dugo V, Massignam AM, Montemorro F (2012) A species-specific critical nitrogen dilution curve for sunflower (Helianthus annuus L.). Field Crop Res 136: 26-34. https://doi.org/10.1016/J.fcr2012.07.024

Devienne-Barret F, Justes E, Machet JM, Mary B (2000) Integrated control of nitrate uptake by crop growth rate and soil nitrate availability under field conditions. Ann Bot 86:995-1005. https://doi.org/10. 1006/anbo.2000.1264

Dimes J, Rodriguez D, Potgieter A (2015) Raising productivity of maizebased cropping systems in eastern and southern Africa: step-wise intensification options. In: Sadras VO, Calderini DF (eds) Crop physiology: applications for genetic improvement and agronomy, 2nd edn. Academic Press, San Diego, pp 93-110 ISBN: 978-0-124171046

Divito GA, Echeveria HE, Andrade FH, Sadras VO (2016) Soybean shows an attenuated nitrogen dilution curve irrespective of maturity group and sowing date. Field Crop Res 186:1-9. https://doi.org/10. 1016/j.fcr2015.07.004

Drenovsky RE, Richards JH (2004) Critical N:P values: predicting nutrient deficiencies in desert shrublands. Plant Soil 259:59-69. https:// doi.org/10.1023/B:PLSO.0000020945.09809.3d

Duncan EG, O’Sullivan CA, Roper MM, Biggs JS, Peoples MB (2018) Influence of co-application of nitrogen with phosphorus, potassium and sulphur on the apparent efficiency of nitrogen fertiliser use, grain yield and protein content of wheat: review. Field Crop Res 226:56-65. https://doi.org/10.1016/j.fcr2018.07.010

Durand J-L, Lemaire G, Gosse G, Chartier M (1989) Analyse de la conversion de l'énergie solaire interceptée par un peuplement de luzerne (Medicago sativa L.) soumis à un déficit hydrique. Agronomie 9(6):599-607

Durand J-L, Varlet-Grancher C, Lemaire G, Gastal F, Moulia B (1991) Carbon partitioning in forage crops. Acta Biotheor 39:213-224

Duru M, Ducrocq H (1997) A nitrogen and phosphorus herbage nutrient index as a tool for assessing the effect of $\mathrm{N}$ and $\mathrm{P}$ supply on the dry matter yield of permanent pastures. Nutr Cycl Agroecosyst 47:5969

Duru M, Thellier L (1997) N and P-K status of herbage : use for diagnosis of grasslands. In: Lemaire G, Barns I (eds) Diagnostic procedures for crop $\mathrm{N}$ management and decision making. Science Update, INRA Editions, Paris

Duru M, Sos L, Viard R (1992) Diagnostic de la nutrition minérale de prairies permanentes au printemps: I. Établissement de références. Agronomie, EDP Sciences, pp 219-233

Evans G C (1972) The quantitative analysis of plant growth, Vol. 1. Blackwell Scientific Publications

Evans GC, Hughes AP (1961) Plant growth and the aerial environment. New Phytol 60:150-180

Farrar JF (1988) Temperature and the partitioning of the translocated carbon. In: Long SP, Woodwards FI (eds) Plants and Temperature. Cambridge University Press, Cambridge, pp 203-235

Farrugia A, Gastal F, Scholefield D (2004) Assessment of the nitrogen status of grassland. Grass Forage Sci 59:113-120. https://doi.org/10. 1111/j.1365-2494.2004.00411.x

Fischer RA, Connor DJ (2018) Issues for cropping and agricultural science in the next 20 years. Field Crops Res 222:121-142. https://doi. org/10.1016/j.fcr.2018.03.008

Fischer RA, Stockman YM (1986) Increased kernel number in Norin 10derived dwarf wheat — evaluation of the cause. Aust J Plant Physiol 13:767-784

Galloway JN, Cowling EB (2002) Reactive nitrogen and the world: 200 years of change. Ambio 3:64-71

Gastal F, Bélanger G (1993) The effect of nitrogen fertilization and the growing season on photosynthesis of field grown tall fescue canopies. Ann Bot 72:401-408 
Gastal F, Lemaire G (2002) N uptake and distribution in crops: an agronomical and ecophysiological perspective. J Exp Bot 53:789 799

Gastal F, Nelson CJ (1994) Nitrogen use within the growing leaf blade of tall fescue. Plant Physiol 105:191-197

Gastal F, Saugier B (1989) Relationships between nitrogen uptake and carbon assimilation in whole plant of tall fescue. Plant Cell Environ 12:407-418

Gastal G, Bélanger G, Lemaire G (1992) A model of the leaf extension rate of tall fescue in response to nitrogen and temperature. Ann Bot 70:437-442

Gastal F, Lemaire G, Durand J-L, Louarn G (2014) Quantifying crop responses to nitrogen and avenues to improve nitrogen-use efficiency. In: Sadras VO, Calderini DF (eds) Crop Physiology, application for genetic improvement and agronomy. Academic Press, Oxford, pp 161-206 ISBN: 978-0-12-4171046

Gerardeaux G, Jordan-Meille L, Constantin J, Pellerin S, Dingkuhn M (2010) Changes in plant morphology and dry matter partitioning caused by potassium deficiency in Gossypium hirsutum (L.). Environ Exp Bot 67:451-459. https://doi.org/10.1016/j.enexpbot. 2009.09.008

Gosse G, Chartier M, Lemaire G (1984) Mise au point d'un modèle de prévision de production pour une culture de luzerne. C R Acad Sci Paris 298(18):541-544

Greenwood DJ, Karpinets TV (1997) Dynamic model for the effects of K fertilizer on crop growth, $\mathrm{K}$-uptake and soil-K in arable cropping.1 - description of the model. Soil Use Manag 13:178-183

Greenwood DJ, Stone DA (1998) Prediction and measurement of the decline in the critical-K, the maximum- $\mathrm{K}$ and total cation plant concentrations during growth of field vegetable crops. Ann Bot 82:871881

Greenwood DJ, Lemaire G, Gosse G, Cruz P, Draycott A, Neeteson JJ (1990) Decline in percentage N of C3 and C4 crops with increasing plant mass. Ann Bot 66:425-436

Greenwood DJ, Karpinets TV, Stone DA (2001) Dynamic model for the effects of soil $\mathrm{P}$ and fertilizer $\mathrm{P}$ on crop growth, $\mathrm{P}$-uptake and soil $\mathrm{P}$ in arable cropping: model description. Ann Bot 88:279-291

Greenwood DJ, Karpinets TV, Zhang K, Bosh-Serra A, Boldrini A, Karawulova L (2008) A unifying concept for the dependence of whole-crop N:P ratio on biomass: theory and experiment. Ann Bot 102:967-977. https://doi.org/10.1093/aob/men188

Grindlay DJC (1997) Towards an explanation of crop nitrogen demand based on leaf nitrogen per unit leaf area. J Sci Food Agric 63:116123

Grindlay DJC, Sylvester-Bradley R, Scott RK (1993) Nitrogen uptake of young vegetative plants in relation to green area. J Sci Food Agric 63:116-123

Güsewell S, Koerselman W, Verhoeven JTA (2003) Biomass N:P ratios as indicators of nutrient limitation for plant populations in wetlands. Ecol Appl 13:372-384. https://doi.org/10.1111/j.1469-8137.2005. 01320.x

Hardwick RC (1987) The nitrogen content of plants and the self-thinning rule of plant ecology: a test of the core-shin hypothesis. Ann Bot 60: 439-446

Hirose T, Werger MJA (1987) Maximising daily canopy photosynthesis with respect to the leaf-nitrogen allocation pattern in the canopy. Oecologia 72:520-526

Hoogmoed M, Sadras VO (2018) Water stress scatters nitrogen dilution curves in wheat. Frontiers (in press). https://doi.org/10.3389/fpls. 2018.00406

Hoogmoed M, Neuhaus A, Noack S, Sadras VO (2018) Benchmarking wheat yield against crop nitrogen status. Field Crops Res 222:153163. https://doi.org/10.1016/j.fcr.2018.03.013

Jobbágy EG, Sala OE (2014) The imprint of crop choice on global nutrient needs. Environ Res Lett 9:084014 (10pp). https://doi.org/10. 1088/1748-9326/9/8/084014
Jones JW, Hoogenboom G, Porter CH, Boote KJ, Batchelorc WD, Hunt LA, Wilkens PW, Singh U, Gijsman AJ, Ritchie JT (2003) The DSSAT cropping system model. Eur J Agron 18:235-265. https:// doi.org/10.1016/S1161-0301(02)00107-7

Jordan-Meille L, Pellerin S (2004) Leaf area establishment of a maize (Zea mays L.) field crop under potassium deficiency. Plant Soil 265: 75-92. https://doi.org/10.1007/s11104-005-0695-z

Justes E, Jeuffroy M-H, Mary B (1997) The nitrogen requirement of major agricultural crops. Wheat, barley and durum wheat. In: Lemaire G, Gastal F (eds) Diagnosis of the nitrogen status in crops. Springer, New York, pp 73-89

Kamprath EJ (1987) Enhanced phosphorus status of maize resulting from nitrogen fertilization of high phosphorus soils. Soil Sci Am J 5I: $1522-\mathrm{I} 526$

Keating BA, Carberry PS, Hammer GL, Probert ME, Robertson MJ, Holzworth D, Huth NI, Hargreaves JNG, Meinke H, Hochman Z, McLean G, Verburg K, Snow V, Dimes JP, Silburne M, Wang E, Brown S, Bristow KL, Asseng S, Chapman S, McCown RL, Freebairn DM, Smith CJ (2003) An overview of APSIM, a model designed for farming systems simulation. Eur J Agron 18:267-288. https://doi.org/10.1016/S1161-0301(02)00108-9

Körner C (1991) Some overlooked plant characteristics as determinants of plant growth: a reconsideration. Funct Ecol 5:162-173

Kunrath TR, Lemaire G, Sadras VO, Gastal F (2018) Water use efficiency in perennial forage species: interactions between nitrogen nutrition and water deficit. Field Crop Res 222:1-11. https://doi.org/10.1016/ j.fcr.2018.02.031

Lambers $H$ (1983) The functional equilibrium, nibbling on the edges of a paradigm. Neth J Agr Sci 31:305-311

Lavorel S, Garnier E (2002) Predicting changes in community composition and ecosystem functioning from plants traits revisiting Holy Grail. Funct Ecol 16:545-556. https://doi.org/10.1046/j.13652435.2002.00664.x

Lejay L, Tillard P, Lepetit M et al (1999) Molecular and functional regulation of two nitrate uptake systems by $\mathrm{N}$ and C-status of Arabidopsis plants. Plant J 18:509-519

Lemaire G (2015) Crop response to N deficiency. In: Encyclopedia of Sustainability Science and Technology, Springer Science, Business Media, New York

Lemaire G, Gastal F (1997) N uptake and distribution in plant canopies. In: Lemaire G (ed) Diagnosis of the nitrogen status in crops. Springer-Verlag, Heidelberg, pp 3-33

Lemaire G, Millard P (1999) An ecophysiological approach to modelling resource fluxes in competing plants. J Exp Bot 330:15-28

Lemaire G, Salette J (1984a) Relation entre dynamique de croissance et dynamique de prélèvement d'azote pour un peuplement de graminées fourragères. I - etude de l'effet du milieu. Agronomie 4(5):423-430

Lemaire G, Salette J (1984b) Relation entre dynamique de croissance et dynamique de prélèvement d'azote pour un peuplement de graminées fourragères. II — etude de la variabilité entre génotypes. Agronomie 4(5):431-436

Lemaire G, Durand J-L, Lila M (1989) Effet de la sécheresse sur la valeur énergétique et azotée de la luzerne (Medicago sativa L.). Agronomie 9(9):841-848

Lemaire G, Onillon B, Gosse G, Chartier M, Allirand JM (1991) Nitrogen distribution within a lucerne canopy during regrowth: relation with light distribution. Ann Bot 68:483-488

Lemaire G, van Oosterom E, Sheehy J, Jeuffroy MH, Massignam A, Rossato L (2007) Is crop demand more closely related to dry matter accumulation of leaf area expansion during vegetative growth? Field Crops Res 100:91-106. https://doi.org/10.1016/j.fcr.2006.05.009

Lemaire G, Jeuffroy MH, Gastal F (2008) Diagnosis tool for plant and crop $\mathrm{N}$ status in vegetative stage. Theory and practices for crop $\mathrm{N}$ management. Eur J Agron 28:614-624. https://doi.org/10.1016/j. eja.2008.01.005 
Liebscher G (1895) Untersuchungen über die Bestimmung des Düngerbedürfnisses der Ackerböden und Kulturpflanzen. J Landwirtsch 43(1895):49-216

Machet J-M, Dubrulle P, Damay N, Duval R, Julien J-L, Recous S (2017) A dynamic decision-making tool for calculating the optimal rates of $\mathrm{N}$ application for 40 annual crops while minimising the residual level of mineral $\mathrm{N}$ at harvest. Agronomy 7:73. https://doi.org/10. 3390/agronomy7040073

McConnaughay KDM, Coleman JS (1999) Biomass allocation in plants: ontogeny or optimality? A test along three resource gradients. Oecologia 113:447-455

Minchin PEH, Thorpe MR, Farrar JF (1993) A simple mechanistic model of phloem transport which explains sink priority. J Exp Bot 44:947955

Monjardino M, McBeath TM, Brennan L, Llewellyn RS (2013) Are farmers in low-rainfall cropping regions under-fertilising with nitrogen? A risk analysis. Agric Syst 116:37-51. https://doi.org/10.1016/ j.agsy.2012.12.007

Monjardino M, Mcbeath T, Ouzman J, Llewellyn R, Jones B (2015) Farmer risk-aversion limits closure of yield and profit gaps: a study of nitrogen management in the southern Australian wheat belt. Agric Syst 137:108-118. https://doi.org/10.1016/j.agsy.2015.04.006

Monteith JL (1972) Solar radiation and productivity in tropical ecosystems. J Appl Ecol 9:747-766

Monteith JL (1994) Principles of resource capture by crop stands. In: Monteith JL, Scott RK, Unsworth MH (eds) Resource capture by crops. Nottingham University Press, Nottingham, pp 1-15

Muchow RC, Sinclair TR (1993) Effect of nitrogen supply on maize yields. II. Field and model analysis. Agron J 87:642-648

Neuhaus A, Sadras VO (2018) Relationship between rainfall-adjusted nitrogen nutrition index and yield of wheat in Western Australia. J Plant Nutr (in press) 41:2637-2643

Niklas KJ (1994) Plant allometry. Univ. of Chicago Press, Chicago

Niklas KJ, Owens T, Reich PB, Cobb ED (2005) Nitrogen/phosphorus leaf stoichiometry and the scaling of plant growth. Ecol Lett 8:636642. https://doi.org/10.1111/j.1461-0248.2005.00759.x

Peng S, Buresh RJ, Huang J, Zhong X, Zou Y, Yang J, Wang G, Liu Y, Hu $\mathrm{R}$, Tang Q (2010) Improving nitrogen fertilization in rice by sitespecific N management: a review. Agron Sustain Dev 30:649-656. https://doi.org/10.1051/agro/2010002

Plénet D, Cruz P (1997) The nitrogen requirement of major agricultural crops. Maize and sorghum. In: Lemaire G, Gastal F (eds) Diagnosis of the nitrogen status in crops. Springer, New York, pp 93-105

Plénet D, Mollier A, Pellerin S (2000) Growth analysis of maize field crops under phosphorus deficiency. II. Radiation-use efficiency, biomass accumulation and yield components. Plant Soil 224:259-272

Ratjen AM, Lemaire G, Kage H, Plénet D, Justes E (2018) Key variables for simulating leaf area and $\mathrm{N}$ status: biomass based relations versus phenology driven approaches. Eur J Agron 100:110-117. https:// doi.org/10.1016/j.eja.2018.04.008

Ravier C, Jeuffroy M-H, Meynard J-M (2016) Mismatch between a science-based decision tool and its use: the case of the balancesheet method for nitrogen fertilization in France. NAJS-Wagening J Life Sci 79:31-40. https://doi.org/10.1016/j.njas.2016.10.001

Ravier C, Jeuffroy M-H, Gate P, Cohan J-P, Meynard J-M (2018) Combining user involvement with innovative design to develop a radical new method for managing $\mathrm{N}$ fertilization. Nutr Cycl Agroecosyst 110:117-134. https://doi.org/10.1007/s10705-0179891-5

Reich PB, Oleksyn J, Wright IJ, Niklas KJ, Hedin L, Elser JJ (2010) Evidence of a general 2/3-power law of scaling leaf nitrogen to phosphorus among major plant groups and biomes. Proc R Soc B Biol Sci 277:877-883. https://doi.org/10.1098/rspb.2009.1818

Reussi Calvo N, Echeverria H, Sainz Rozas H (2011) Diagnosing sulfur deficiency in spring red wheat: plant analysis. J Plant Nutr 34:573589
Sackville-Hamilton NR, Matthew C, Lemaire G (1995) In defence of the $-3 / 2$ boundary rule : a reevaluation of self-thinning concepts and status. Ann Bot 76:569-577

Sadras VO (2006) The N:P stoichiometry of cereal, grain legume and oilseed crops. Field Crops Res 95:13-29. https://doi.org/10.1016/j. fcr.2005.01.020

Sadras VO, Lemaire G (2014) Quantifying crop nitrogen status for comparisons of agronomic practices and cultivars. Field Crop Res 164: 54-64. https://doi.org/10.1016/j.fcr.2014.05.006

Sadras VO, O'Leary GJ, Roget DK (2005) Crop responses to compacted soil: capture and efficiency in the use of water and radiation. Field Crops Res 91:131-148. https://doi.org/10.1016/j.fcr.2004.06.011

Sadras VO, Lawson C, Montoro A (2012) Photosynthetic traits of Australian wheat varieties released between 1958 and 2007. Field Crops Res 134:19-29. https://doi.org/10.1016/j.fcr.2012.04.012

Salette J (1990) The effect of level of nitrogen nutrition upon mineral content and removal in grasses and wheat. Fert Res 26:229-235

Salette J, Huché L (1991) Diagnostic de 1'état de nutrition minérale d'une prairie par l'analyse minérale du végétal: principes, mise en oeuvre, exemples. Fourrages 125:3-18

Scaife A (1994) Fall in nutrient demand per unit length of root during the linear phase of plant growth. Plant Soil 164:315-317

Schwinning S, Weiner J (1998) Mechanisms determining the degree of size-asymmetry in competition among plants. Oecologia 113:447455

Seginer I (2004) Plant spacing effect on the nitrogen concentration of a crop. Eur J Agron 21:369-377. https://doi.org/10.1016/j.eja.2003. 10.007

Sinclair TR, Amir J (1992) A model to assess nitrogen limitations on the growth and yield of spring wheat. Field Crops Res. 30:63-78

Sinclair TR, Horie (1989) Leaf nitrogen, photosynthesis, and crop radiation use efficiency: a review. Crop Sci 29:90-98

Sinclair TR, Park WI (1993) Inadequacy of the Liebig limiting-factor paradigm for explaining varying crop yields. Agron J 85:742-746

Sinclair TR, Sinclair CJ (2010) Bread, beer and the seeds of change: agriculture's imprint on world history. CAB International, Wallingford ISBN-13: 978-1845937041

Sinclair TR, Mosca G, Bona S (1993) Simulation analysis of variation among season in winter wheat yields in northern Italy. J Agron Crop Sci 170:202-207

Sinclair TR, Muchow RC, Monteith JL (1997) Model analysis of sorghum response to nitrogen in soubtropcial and tropical environments. Agron J 89:201-207

Smith PF (1962) Mineral analysis of plant tissues. Ann Rev Plant Physiol 13:81-108

Soltani A, Sinclair TR (2012) Modeling physiology of crop development, growth and yield. CABI, Wallingford ISBN-13: 9781845939700

Soltani A, Sinclair TR (2015) A comparison of four wheat models with respect to robustness and transparency: simulation in temperate, sub-humid environment. Field Crops Res 175:37-46. https://doi. org/10.1016/j.fcr.2014.10.019

Soltani A, Maddah V, Sinclair TR (2013) SSM-wheat: a simulation model for wheat development, growth and yield. J Plant Prod 7:711-740 ISSN: 1735-6814 (Print), 1735-8043 (Online)

Stearns SC (1992) The evolution of life histories. Oxford University Press, Oxford

Sylvester-Bradley R, Stokes DT, Scott RK, Willington VBA (1990) A physiological analysis of the diminishing responses of winter wheat to applied nitrogen. 2. Evidence. Asp Appl Biol II Cereal Qual 25: 289-300

Tahir Ata-Ul-Karim S, Liu X, Lu Z, Yuan Z, Zhu Y, Cao W (2016) Inseason estimation of rice grain yield using critical nitrogen dilution curve. Field Crops Res 195:1-8. https://doi.org/10.1016/j.fcr.2016. 04.027

Thomas H, Ougham H (2015) Senescence and crop performance. In: Sadras VO, Calderini DF (eds) Crop physiology: applications for 
genetic improvement and agronomy. Academic Press, San Diego, pp 223-250

Tilman D, Cassman KG, Matson PA, Naylor R, Polasky S (2002) Agricultural sustainability and intensive production practices. Nature 418(6898):671-677

Trapani N, Hall AJ, Weber M (1999) Effects of constant and variable nitrogen supply on sunflower (Helianthus annuus L.) leaf cell number and size. Ann Bot 84:599-606

Valkama ER, Uusitalo R, Turtola E (2011) Yield response models to phosphorus application: a research of Finnish field trials to optimize P use of cereals. Nutr Cycl Agroecosyst 91:1-15

Valle SR, Pinochet D, Calderini DF (2009) Al toxicity effects on radiation interception and radiation use efficiency of Al-tolerant and Alsensitive wheat cultivars under field conditions. Field Crops Res. 114:343-350

von Liebig J (1855) Die Grundsätze der Agricultur-Chemie mit Rücksicht auf die in England agestellien Untershchungen. 2nd edition, Graunschweig

Walworth JL, Summer ME (1987) The diagnosis and recommendation integrated system (DRIS). Adv Soil S 6:149-188

Weiner J (2004) Allocation, plasticity and allometry in plants. Perspect Plant Ecol 6:207-215. https://doi.org/10.1078/1433-8319-00083

Yao X, Zhu Y, Tian YC, Feng W, Cao WX (2010) Exploring hyperspectral bands and estimation indices for leaf nitrogen accumulation in wheat. Int J Appl Earth Obs 12:89-100. https://doi.org/ 10.1371/journal.pone.0096352

Yoda K, Kira T, Ogawa H, Hozumi H (1963) Intraspecific competition among higher plants. XI-self-thinning in over-crowded pure stands under cultivated and natural conditions. J Biol Osaka City Univ 14: $107-129$

Youssefian S, Kirby EJM, Gale MD (1992) Pleiotropic effects of the Gainsensitive Rht dwarfing genes in wheat .2. Effects on leaf, stem, ear and floret growth. Field Crops Res 28:191-210

Zhao Z, Wang E, Wang Z, Zang H, Liu Y, Angus JF (2014) A reappraisal of the critical nitrogen concentration of wheat and its implications on crop modeling. Field Crops Res 164:65-73. https://doi.org/10.1371/ journal.pone.0096352

Zhao B, Liu ZD, Ata-Ul-Karim ST, Xiao JF, Liu ZG, Qi AZ, Ning DF, Nan JQ, Duan AW (2016) Rapid and nondestructive estimation of the nitrogen nutrition index in winter barley using chlorophyll measurements. Field Crops Res 185:59-68. https://doi.org/10.1016/j.fcr. 2015.10.021

Ziadi N, Bélanger G, Cambouris A, Tremblay N, Nolin MC, Claessens A (2007) Relationship between P and N concentration in corn. Agron J 99:833-841. https://doi.org/10.2134/agronj2006.0199

Ziadi N, Bélanger G, Cambouris A, Tremblay N, Nolin MC, Claessens A (2008a) Relationship between phosphorus and nitrogen concentrations in spring wheat. Agron J 100:80-86. https://doi.org/10.2134/ agronj2007.0119

Ziadi N, Brassard M, Bélanger G, Cambouris A, Tremblay N, Nolin MC, Claessens A, Parent L-E (2008b) Critical curve and nitrogen nutrition index for corn in eastern Canada. Agron J 100:271-276. https:// doi.org/10.2134/agronj2007.0059

Ziadi N, Brassard M, Bélanger G, Claessens A, Tremblay N, Cambouris A, Nolin MC, Parent L-E (2008c) Chlorophyll measurements and nitrogen nutrition index for the evaluation of corn nitrogen status. Agron J 100:1264-1273. https://doi.org/10.2134/agronj2008.0016

Ziadi N, Bélanger G, Gastal F, Claessens A, Lemaire G, Tremblay N (2009) Leaf nitrogen concentration as an indicator of corn nitrogen status. Agron J 101:947-957. https://doi.org/10.2134/agronj2008. 0172x

Ziadi N, Bélanger G, Claessens A, Lefebvre L, Cambouris AN, Tremblay N, Nolin MC, Parent L-E (2010a) Determination of a critical nitrogen dilution curve for spring wheat. Agron J 102:241-250. https:// doi.org/10.2134/agronj2009.0266

Ziadi N, Bélanger G, Claessens A, Lefebvre L, Tremblay N, Cambouris AN, , Nolin MC, Parent L-E (2010b) Plant-based diagnostic tools for evaluating wheat nitrogen statusCrop Sci. 50:2580-2590. https:// doi.org/10.2135/cropsci2010.01.0032

Publisher's note Springer Nature remains neutral with regard to jurisdictional claims in published maps and institutional affiliations. 